Date of Publication: $18 / 12 / 2012$

\section{Cunninghamia}

A journal of plant ecology for eastern Australia

ISSN $0727-9620$ (print) • ISSN 2200 -405X (Online)

\title{
The vegetation of the Mount Murchison and Wilga areas, Paroo Darling National Park, western New South Wales
}

\author{
M. Westbrooke ${ }^{1}$, S. Gowans ${ }^{1}$ and M. Gibson ${ }^{1,2}$ \\ ${ }^{1}$ Centre for Environmental Management, University of Ballarat, PO Box 663 Ballarat, Victoria, 3353, AUSTRALIA. \\ ${ }^{2}$ Biosis Research Pty. Ltd., PO Box 18N Ballarat, Victoria, 3353, AUSTRALIA.
}

\begin{abstract}
The vegetation of the Mount Murchison and Wilga areas, Paroo Darling National Park (latitude $31^{\circ} 00^{\prime}-32^{\circ} 40^{\prime} \mathrm{S}$ and longitude $142^{\circ} 10^{\prime}-144^{\circ} 25^{\prime} \mathrm{E}$ ) in north western New South Wales was assessed using intensive quadrat sampling and mapped using extensive ground truthing and interpretation of aerial photograph and Landsat Thematic Mapper satellite images. In the survey 237 vascular plant species including 37 (15.6\%) exotic species, from 46 families were recorded. Seventeen vegetation communities were identified and mapped, 15 for Mount Murchison area and 13 for the Wilga area. The most widespread for Mount Murchison being Maireana pyramidata low open shrubland, Flindersia maculosa low open woodland, Muehlenbeckia florulenta open shrubland and Eucalyptus coolabah / Eucalyptus largiflorens open woodland. The most widespread for Wilga being Muehlenbeckia florulenta open shrubland and Eucalyptus coolabah / Eucalyptus largiflorens open woodland. Many of these communities have been impacted by a history of 150 years of pastoral use.
\end{abstract}

Cunninghamia (2012) 12 (4): 339-361

doi: 10.7751/cunninghamia.2012.12.024

\section{Introduction}

Paroo Darling National Park (latitude $31^{\circ} 00^{\prime}-32^{\circ} 40^{\prime} \mathrm{S}$ and longitude $142^{\circ} 10^{\prime}-144^{\circ} 25^{\prime} \mathrm{E}$ ) is located in north-western New South Wales, north-east of the town of Wilcannia (Fig. 1). The park was created in October 2002, incorporating the previously gazetted Peery National Park (created from three pastoral stations: Peery, Mandalay and Arrow Bar) with the addition of Coonavitra, Mount Murchison, Wilga and Tilpilly Stations. The Park now covers an area of approximately 221,000 hectares.

Paroo Darling National Park is made up of six separate areas (Fig 1). The pastoral stations Peery, Mandalay and Arrow Bar together make up the northern most area of the park known as the Peery Lake area (formerly Peery National Park). The Mount Murchison area and the Wilga area are separated by the Darling River. The Tillpilly area is the eastern most extent of the park situated between the Barrier Highway and the Wilcannia-Bourke Road. The Coonavitra area is southeast of these areas, consisting of blocks both north and south of the Barrier Highway.

Major features of the park are the Darling River that flows between the Mount Murchison and Wilga areas, Peery Lake which is a part of the Paroo Overflow, the rugged sandstone hills to the west of the lake, and the rugged Greenough Hill range of the Northern block of the Coonavitra area.

Detailed floristic survey and vegetation mapping has been completed for the Peery Lake area (Westbrooke et al. 2002; Westbrooke et al. 2003) and the Tilpilly area (Hunter \& Fallavollita 2003). In June and November 2005 an intensive vegetation survey was conducted of the Wilga, Mount Murchison and Coonavitra blocks (Westbrooke et al. 2006a; Westbrooke et al. 2006b). The vegetation of the Coonavitra block is documented in Westbrooke et al. (2011), and this paper presents the results of the survey of the Mount Murchison and Wilga blocks. 


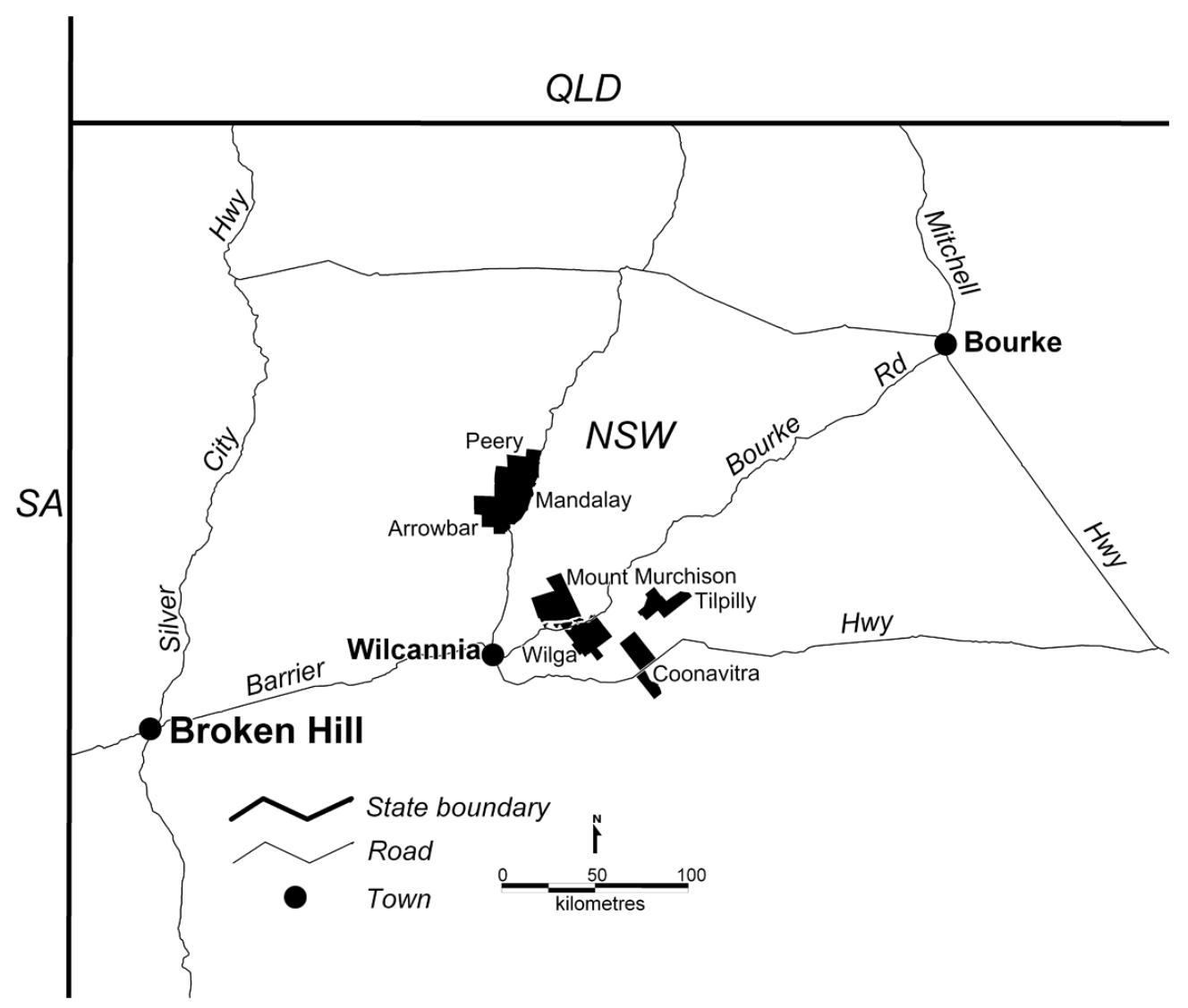

Fig. 1. Location of Paroo Darling National Park

\section{History of the area}

The area is part of the country of the Paakantyi people which extends from Bourke down the Darling River to its junction with the Murray River at Wentworth (Hercus 1993). The large number of middens and stone relics encountered today provides evidence of their strong ties to the river $(\mathrm{H}$. Johnston, New South Wales Parks and Wildlife Service, Buronga, pers. comm.).

The first European to visit the area was Charles Sturt who named the Darling River in honour of Sir Ralf Darling, then Governor of the colony of New South Wales, in 1828. Surveyor General Thomas Mitchell followed in 1835 and after travelling down the eastern side of the Darling from what is now Bourke he crossed the Darling near the site of Wilcannia and climbed a hill which he named Mt Murchison. Sturt later followed the Darling River to Menindee and then travelled west to the Barrier Range and north into Queensland (Stanley 1991). Soon after, others followed the Darling River in search of pasture for sheep. Between 1855 and 1860 Hugh and Bushby Jamieson leased a number of runs near the Paroo-Darling junction which were managed together as Mt Murchison Station (Hope \& Linsday 2010). The township of Wilcannia was surveyed in 1865 and soon thrived (Hardy 1969). Previously there was just a woolshed and a few huts at Mount Murchison Station. Soon after, 38 runs were taken up as Momba (848,000 ha.) which incorporated the existing Mount Murchison lease (Pickard 1990). Smith, Elder and
Waite held the Momba pastoral lease from early 1870 (Heathcote 1965). In 1889 it was reported that Momba was overrun by kangaroos (Heathcote 1965). About this time a party of shooters found opal in the sandstone hills and by the 1890s White Cliffs township was established (Hardy 1969). With the development of pastoral leases in the 1850 s, Aboriginal people were moved from their traditional homes to government missions at Menindee, Ivanhoe and Lake Cargelligo.

The combination of drought and overstocking made the normal recurrence of drought a major disaster. Whereas the land returned rapidly from 'desert' to 'vital glory' after the 1865-70 drought, this was no longer the case by the end of the century. By 1901 there was a catastrophic decline in productivity in the West Darling area. Sheep numbers went from less than two million prior to 1880 to a peak of nearly eight million by 1894 but had declined to less than three million again by 1901 . From 1902, Momba was successively subdivided until around 1950 when the residue was divided into ten leases which included Peery, Mandalay, Arrow Bar and Mt Murchison (Pickard 1990).

Peery Station was acquired in 1999 by the NSW government to protect its significant natural and cultural heritage values. Peery National Park was proclaimed in March 2000 (NPWS 2000), and the additions of the Arrow Bar and Mandalay leases in December 2000 gave protection to the entire Peery Lake basin. 
In June 2001, the Mount Murchison lease on the northern side of the Darling River was acquired followed by Coonavitra in June 2000. Finally the purchase of Wilga Station, bordering Mount Murchison on the southern bank of the Darling in April 2002 provided a link between the northern and southern properties and led to the proclamation of Paroo Darling National Park, incorporating what had previously been the Peery National Park in October 2002.

The Mount Murchison Station that became part of the Paroo Darling National Park was part of the original Momba Station. The modern Mount Murchison Station dated from March 1926 when the southern part of Momba was subdivided and offered for sale in nine lots, two of them being individual paddocks situated on the banks of the Darling River. Arthur Crossing, a butcher from Cobar, acquired the property and owned it until 1945 when it was sold to William Cook and Edward Marr. Marr acquired Cook's share in 1954. Ownership of the station was put it in the name of Mount Murchison Pty Ltd in March 1983 and the New South Wales National Parks and Wildlife Service acquired most of the Mount Murchison lease in June 2001. Marr retained a small portion of the lease that includes the Mount Murchison homestead.

Wilga Station was formed from the resumed areas of two earlier stations. The present homestead block was originally part of Cultowa Station, while two paddocks added in the 1940s were originally part of Murtee Station. John Plant took over the lease in 1925 . The station was divided by watercourses that fed water from the river into large lakes with many parts of the property subject to flooding when the river was high. Pastoral inspectors reports (1963-2001) indicate the stocking levels over several years included 4-8,000 sheep and up to 600 head of cattle. Following John Plant's death in 1960 the property passed to other family members. From July 1985 a cultivation permit enabled cropping on 6175 ha of floodplain country. Raymond Plant died in 1994. Probate issues took some time to conclude and the property was sold to the New South Wales National Parks and Wildlife Service in February 2002 (NPWS 2002).

\section{Climate}

The climate for the area is described as arid with low and unreliable rainfall (Edwards 1979). Temperatures are high in summer and mild in winter with average daily maximum of $35^{\circ} \mathrm{C}$ in January and $17^{\circ} \mathrm{C}$ in July and average daily minimum of $21^{\circ} \mathrm{C}$ in January and $4^{\circ} \mathrm{C}$ in July. The mean annual rainfall is approximately $250 \mathrm{~mm}$ and annual potential evaporation is $2738 \mathrm{~mm}$. There is a slight summer bias to rainfall and annual variation is high (Clewett et al. 1994).

\section{Land systems}

The Mount Murchison area supports a large expanse of sand plains to the north and alluvial plains adjacent to the Darling

Table 1. Land systems present across the Mount Murchison and Wilga areas (source Walker 1972; Hazelton 1977)

\begin{tabular}{|c|c|c|}
\hline \multicolumn{3}{|l|}{ Plains } \\
\hline Oulila (Ou) & Mount Murchison & $\begin{array}{l}\text { Slightly undulating plain with few sandy rises, pans and larger drainage sinks. Relief to } 5 \mathrm{~m} \text {. Red } \\
\text { textured contrast soils and red earths. }\end{array}$ \\
\hline Vidale (Vi) & Mount Murchison & $\begin{array}{l}\text { Plain with calcareous red earths and solonized brown soils with sandy to loamy surface. Relief to } \\
3 \mathrm{~m} \text {. }\end{array}$ \\
\hline \multicolumn{3}{|r|}{ 1. } \\
\hline Budda (Bd) & Wilga & $\begin{array}{l}\text { Undulating plains with recent and ancient dunes, areas of active floodplain. Relief to 10m. Plains } \\
\text { with sandy yellow texture-contrast and alluvial soils. Intrusions of grey cracking clays. }\end{array}$ \\
\hline Denian (De) & $\begin{array}{l}\text { Mount Murchison \& } \\
\text { Wilga }\end{array}$ & $\begin{array}{l}\text { Slightly undulating plains, dunes and alluvial plains bordering floodplains. Relief to } 5 \mathrm{~m} \text {. Plains } \\
\text { with yellow texture-contrast and alluvial soils. }\end{array}$ \\
\hline Dunoak (Do) & Wilga & $\begin{array}{l}\text { Open level plains with occasional sandy rises, drainage sinks, pans and ancient dunes. Relief to } \\
3 \mathrm{~m} \text {. Sandy yellow or red texture-contrast soils, occasional solonized brown soils, areas of cracking } \\
\text { clays with gilgais in drainage sinks and pans. }\end{array}$ \\
\hline Mid Darling (My) & $\begin{array}{l}\text { Mount Murchison \& } \\
\text { Wilga }\end{array}$ & $\begin{array}{l}\text { Winding perennial stream. Channel incised to } 15 \mathrm{~m} \text {. Grey cracking heavy clay soils with small areas } \\
\text { of scaldy grey clays on and adjacent to river banks. }\end{array}$ \\
\hline Nelyambo (NI) & $\begin{array}{l}\text { Mount Murchison \& } \\
\text { Wilga }\end{array}$ & $\begin{array}{l}\text { Open level floodplain of the Darling River, with grey gilgaid and crab-holey, cracking heavy clays. } \\
\text { Small pans and minor drainage channels with scaldy grey clays, fringing brown and red cracking } \\
\text { clays. }\end{array}$ \\
\hline \multicolumn{3}{|r|}{ (10. } \\
\hline Cobham $(\mathrm{Cb})$ & Mount Murchison & $\begin{array}{l}\text { Salt lakes with bare, flat crusted floors of saturated salty brown clay. Pans with deep self-mulching } \\
\text { brown clays and brown clays with strong surface crusts. Swamp basins and channels with deep } \\
\text { self-mulching brown and grey cracking clays, some with extremely deep and wide cracks. Pan } \\
\text { margins with sandy surfaces over earthy pans. Lunettes with deep, loose sand or loamy sand. }\end{array}$ \\
\hline Paroo Overflow (Po) & Mount Murchison & $\begin{array}{l}\text { Extensive overflows of the Paroo River. Grey cracking clays. Isolated islands of scalded light } \\
\text { brown loamy sands. }\end{array}$ \\
\hline Popelloe (Pp) & Wilga & $\begin{array}{l}\text { Scalded plains with small stranded lakes and swamps, adjacent to large lakes. Red texture-contrast } \\
\text { soils with shallow sandy surface. Small lakes of grey heavy clay, with overlying sandy deposits } \\
\text { around shorelines. }\end{array}$ \\
\hline Thackenbie (Tb) & Wilga & $\begin{array}{l}\text { Small to very large lakes filled by floodwaters from Darling River. Large beds with eastern lunettes } \\
\text { and otherwise level shorelines, narrow interconnecting channels. Beds, shorelines and channels of } \\
\text { grey cracking heavy clays. Lunettes of sandy calcareous or texture-contrast soils. }\end{array}$ \\
\hline
\end{tabular}




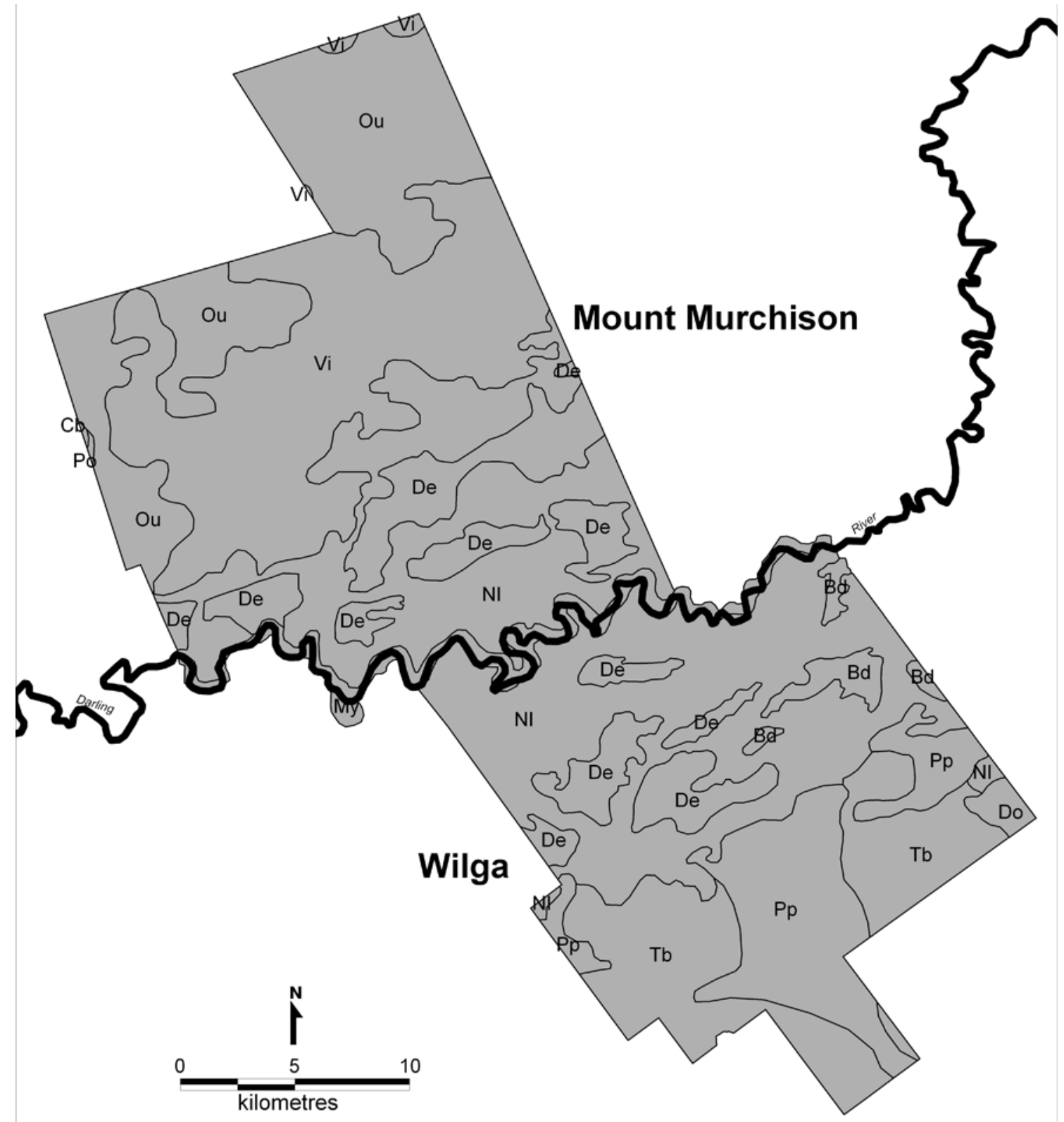

Fig. 2. Distribution of land systems within Mount Murchison and Wilga areas, Paroo-Darling National Park (Key to codes used can be found in Table 1)

River. The Wilga area is mostly made up of alluvial plains of the Darling River together with playas and basins in the south. Seven land systems are described for the Mount Murchison area and seven land systems for the Wilga area by Walker (1972) and Hazelton (1977) (Table 1). The distribution of the land systems across the Mount Murchison and Wilga areas is shown in Fig 2.

\section{Previous studies}

The most complete study of the vegetation of far western New South Wales is that by Beadle (1945; 1948) who classified the study area as Casuarina pauper / Alectryon oleifolius subsp. canescens association along with claypans and swamps associated with the Darling River. Milthorpe
(1991) gave an account of the vegetation of the north-west corner of New South Wales, which included the land that is now known as the Peery Lake area of Paroo Darling National Park. Pickard and Norris (1994) have also given an account of the vegetation of an area of north-west New South Wales. Parts of the area now included in the Park were included in studies undertaken for the Wilderness Society (Lembit 1993; Knight 1994). A detailed survey and vegetation map have been completed for the Peery Lake area (Westbrooke et al. 2002; Westbrooke et al. 2003), the Tilpilly area (Hunter \& Fallavollita 2003) and Coonavitra area (Westbrooke et al. 2006; Westbrooke et al. 2011) of the park. No systematic survey of the vegetation of the Mount Murchison and Wilga areas of the park had been undertaken prior to this study. 


\section{Methods}

\section{Study area}

The Mount Murchison area of Paroo Darling National Park is located approximately $40 \mathrm{~km}$ north-east of Wilcannia. It incorporates approximately 41,600 ha of the former Mount Murchison Station. The Mount Murchison study area is situated to the north of the Darling River and includes around $47 \mathrm{~km}$ of Darling River frontage.

The southern part of the Mount Murchison study area falls within the Darling Riverine Plains bioregion that takes in the riverine corridor and the floodplains of the Darling River. The northern part of the Mount Murchison study area falls within the Mulga Lands bioregion taking in undulating sand plains. The Paroo River flows into the Darling River just west of the study area. Part of the Paroo Overflow extends into the western section of Mount Murchison.

Following significant rainfall and flooding, a number of lakes, swamps and channels on the floodplain adjoining the Darling River carry water. In the south-eastern part of the study area, Jamieson Creek can hold water for prolonged periods after heavy rain. Eight named tanks (McIntyres Plain, Twin, Dead Mans Swamp, Great Eastern, Seawoods Hut, Tallandra, Forest Hut and McQueens Tanks), a few unnamed tanks and three named bores (Eight Mile, Tallandra and Salt Bores) (Fig. 3) were constructed to provide water for stock prior to the park being gazetted.

The Wilga area of Paroo Darling National Park is located approximately $50 \mathrm{~km}$ north-east of Wilcannia on the Wilcannia-Bourke Road and incorporates approximately 33,250 ha of the former Wilga Station. The Wilga study

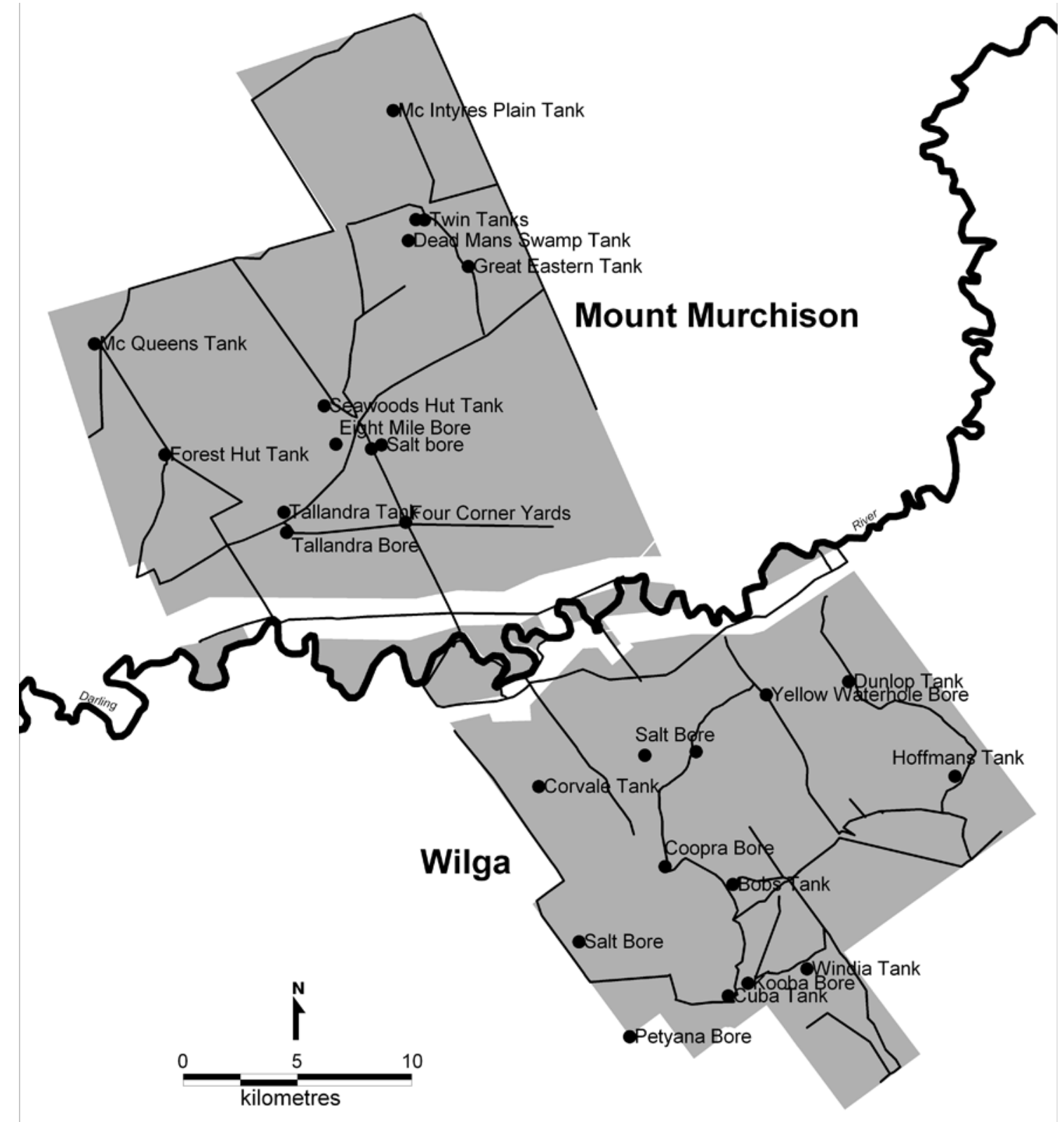

Fig. 3. Survey transects for the Mount Murchison and Wilga areas 
area is bounded to the north-west by the Darling River and includes around $40 \mathrm{~km}$ of Darling River frontage. The Wilga homestead and shearer's quarters are situated on the southern bank of the Darling River just west of Papepapinbilla Creek.

The Wilga study area falls within the Darling Riverine Plains bioregion. There are a number of ephemeral creeks (Talyawalka, Lake, Coopara and Papepapinbilla Creeks), channels and waterholes on the Darling River floodplain. These areas flow or fill for a short time following major rainfall events. The southern part of the study area takes in the northern extents of Poopelloe and Wongalara Lakes. Five named tanks (Dunlop, Bobs, Cuba, Corvale and Windia), a few unnamed tanks and four named bores (Yellow Waterhole, Salt, Coopra and Kooba) (Fig. 3) provided water for stock prior to the park being gazetted.

\section{Transect survey}

A preliminary survey to assess and map the vegetation communities present within the Mount Murchison and Wilga areas of Paroo Darling National Park was undertaken during June 2005, following three years of drought. A transect based sampling strategy was employed. Driven transects followed existing vehicle access tracks and fence lines, and additional walked transects were used to access more remote areas. All transects were tracked using a Global Positioning System (GPS) receiver in the Australian Map Grid projection (Zone 54 and 55) and the 1984 World Geodetic System datum. The survey included approximately $335 \mathrm{~km}$ of transects (Fig. 3).

Vegetation communities along these transects were recorded and dominant perennial species listed for each community. Details of how information was collected along these transect and used to define vegetation communities to produce a vegetation map at a scale of 1: 50,000 are outlined below.

\section{Quadrat survey}

A detailed floristic survey was undertaken during November 2005 following good winter rainfall. A quadrat based sampling strategy was employed to survey the floristic composition of the vegetation communities. All quadrats were $900 \mathrm{~m} 2$ (30 m x $30 \mathrm{~m}$ ) in size. The sampling strategy was based on the preliminary vegetation map prepared following the June survey. Communities were generally sampled in proportion to the area they covered but to enable characterisation of communities, those of limited distribution may have been relatively over-sampled. All quadrat locations were recorded

\section{Table 2. Modified Braun-Blanquet scale (Kershaw \& Looney 1985)}

$\begin{array}{ll}\text { Scale } & \text { Definition } \\ + & \text { Few individuals, less than 1\% cover } \\ 1 & \text { Any number of individuals, less than 5\% cover } \\ 2 & \text { Any number of individuals, } 6-25 \% \text { cover } \\ 3 & \text { Any number of individuals, } 26-50 \% \text { cover } \\ 4 & \text { Any number of individuals, } 51-75 \% \text { cover } \\ 5 & \text { Any number of individuals, } 76-100 \% \text { cover }\end{array}$

using a Global Positioning System (GPS) receiver in the Australian Map Grid projection (Zone 54 and 55) and the 1984 World Geodetic System datum. All vascular plant species occurring in each quadrat were recorded, identified to species level where possible and their conservation status determined. All flora were given a cover / abundance value, modified from Braun-Blanquet scale as cited in Kershaw and Looney (1985) (Table 2).

The field survey was undertaken during early spring following good winter rains to take advantage of the opportunities for plant identification, particularly of grasses, herbs and forbs. Some later spring-flowering grasses, herbs and forbs may have been dormant at this time and not observed. Similarly, earlier spring-flowering plants may have completed their growth cycles and may not have been observed. Where dead material (e.g. leaves, stems, seeds) was available such species were recorded to family, genus or species level where possible.

An estimate of the typical height and a visual estimate of the projected foliage cover of both native and introduced species in the tree layer, tall shrub layer (approximately $>1 \mathrm{~m}$ high), small shrub layer (approximately $<1 \mathrm{~m}$ high) and ground layer were recorded for each quadrat. Visual estimates of the total percentage cover of bare ground, cryptogams, litter, logs and rocks were recorded for each quadrat. All quadrats were photographed to provide a visual record. Forty seven quadrats were sampled for the Mount Murchison area and 55 quadrats for the Wilga area (Fig. 4).

During the November quadrat survey, the 1: 50,000 vegetation map produced following the June field survey was verified by ground checking the mapped boundaries of the vegetation communities via driven transects.

\section{Data analysis}

Information from the transects was used in conjunction with the study of colour aerial photographs (The Department of Lands) and Landsat Thematic Mapper satellite imagery (Scene 95-83) to produce a vegetation map at 1: 50,000 scale. Vegetation mapping was undertaken using a combination of ArcGIS 9.0 and MapInfo Professional Version 7.5 Geographic Information Systems. The mapped vegetation communities were defined by floristic and structural characteristics (Specht 1970) coupled with expert judgment. The communities proposed were related to those outlined in Benson (2006) to determine the equivalent vegetation community name and their conservation status. Most communities with patch sizes of a hectare or greater were mapped as polygons and those of restricted occurrence were located as points on the map.

Data from quadrats were entered into a Microsoft ${ }^{\circledR}$ Access 2002 database. A species list was compiled for the study area incorporating all vascular plant species recorded from quadrats and additional species recorded opportunistically. The flora list also identifies which vegetation community each of the species was recorded in. For each vegetation community, mean species richness, total species richness and mean numbers of introduced species per quadrat were calculated. 


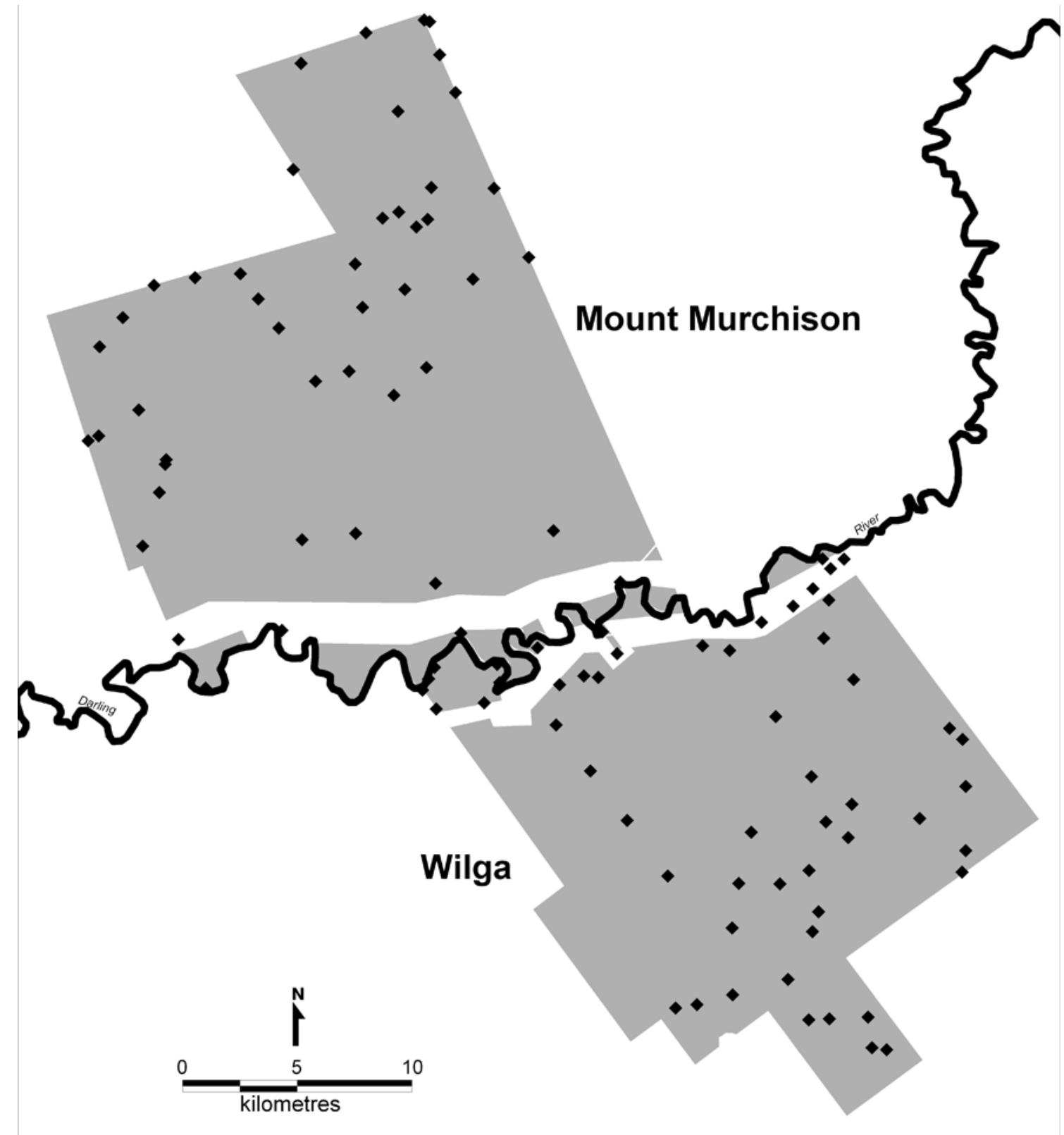

Fig. 4. Quadrat locations for the Mount Murchison and Wilga areas

\section{Results}

\section{Vegetation}

The Mount Murchison area consists of a strip of Eucalyptus camaldulensis open woodland along the banks of the Darling River, Eucalyptus coolabah / Eucalyptus largiflorens open woodland and Muehlenbeckia florulenta open shrubland on the Darling River floodplains, with Maireana pyramidata low open shrubland on the adjoining sandplains. Off the floodplain, Flindersia maculosa low open woodland and Casuarina pauper / Alectryon oleifolius low open woodland occur on level sandplains.

The vegetation of the Wilga area consists predominantly of floodplains of Muehlenbeckia florulenta open shrubland and Eucalyptus coolabah / Eucalyptus largiflorens open woodland. A strip of Eucalyptus camaldulensis open woodland occurs along the banks of the Darling River. The sandplains to the south of the river are variously dominated by Acacia victoriae open shrubland and a mixed open shrubland complex.

Seventeen communities were recognised for the Mount Murchison and Wilga areas, 15 for Mount Murchison area and 13 for the Wilga area. All vegetation communities are identified in Table 3 and are grouped according to structural attributes. While several of these are of limited distribution they add significantly to the conservation values of the Park. The floristic composition of vegetation communities are outlined later in this section. A total list of flora species recorded for each vegetation community is provided in Appendix 1. Appendix 2 shows the distribution of each vegetation community. 


\section{Table 3. Vegetation communities of the Mount Murchison and Wilga areas with their relationship to soil and landform}

Note: The total mapped area is approximately 45,398 ha for the Mount Murchison area and 35,918 ha for the Wilga area. This includes the park and also areas outside the reserve extending to the Darling River. Point locations of communities (i.e. Anthropogenic herbland) have been treated as occupying approximately 1 ha. Equivalent Benson (2006) vegetation community I.D. numbers are shown in brackets.

\section{Vegetation community}

\section{Woodlands}

Atalaya hemiglauca low open woodland (137) 456

Casuarina pauper / Alectryon oleifolius low $\quad$ 1,284 open woodland (58)

Eucalyptus camaldulensis open woodland (36) 242

Eucalyptus coolabah / Eucalyptus largiflorens 5,034 open woodland (38)

Flindersia maculosa low open woodland (144) 9,996

\section{Tall shrublands}

Acacia aneura tall open shrubland (plains) (119) 383

Acacia ligulata tall open shrubland (124)

Hakea leucoptera tall open shrubland (199)

\section{Low shrublands}

Acacia victoriae open shrubland (139)

Atriplex nummularia open shrubland (158)

Eremophila / Dodonaea / Senna open shrubland (143)

Maireana pyramidata low open shrubland (153) 16,785

Muehlenbeckia florulenta open shrubland (25) $\quad 8,718$

\section{Grasslands}

Eragrostis australasica grassland (24)

\section{Herblands}

Anthropogenic herbland

Cropped lakebed

Lakebed herbland (166)
1 Calcareous plains of the Oulila landsystem of Mount Murchison and the Popelloe landsystem of Wilga.

- $\quad$ Calcareous sandplains of the Oulila, Vidale and Denian landsystems.

249 Fringing the Darling River of the Mid-Darling landsystem.

8,113 Darling River floodplain of the Nelyambo landsystem of both Mount Murchison and Wilga, the Denian landsystem of Mount Murchison and the Thackenbie landsystem of Wilga. Fringing lakebeds of the Vidale and Oulila landsystems for Mount Murchison and the Denian and Budda landsystems of Wilga.

1 Aeolian sands and calcareous plains of the Vidale landsystem of Mount Murchison and the Popelloe landsystem of Wilga.

Footslopes of hills of the Oulila landsystem of Mount Murchison.

1,098 Undulating plains and dunes of the Denian landsystem of Wilga

11 Plains of the Oulila and Nelyambo landsystems of Mount Murchison and the Poppelloe landsystem of Wilga.

2,569 Undulating plains and dunes of the Denian landsystem for both Mount Murchison and Wilga, the Nelyambo landsystem of Mount Murchison and the Budda, Dunoak and Popelloe landsystems of Wilga.

- $\quad$ Sub-terminal basins and floodplains of the Paroo River, of the Paroo Overflow and Oulila landsystems of Mount Murchison.

4,604 Sandy rises within alluvial plains of the Popelloe landsystem of Wilga.

Quaternary sandplains of the Oulila, Vidale and Denian landsystems of Mount Murchison.

15,283 Lakebeds of Darling River floodplain of the Nelyambo landsystem of both Mount Murchison and Wilga and the Thackenbie landsystem of Wilga.

116 Lakes and depressions within quaternary plains of the Oulilla landsystem of Mount Murchison and the Popelloe landsystem of Wilga.

14 Areas subject to significant disturbance, including earth tanks and yards. 910 Darling River floodplain lakes.

2,768 Darling River overflow lakes and floodplains of the Nelyambo landsystem of both Mount Murchison and Wilga, the Oulila and Vidale landsystems of Mount Murchison and the Thackenbie landsystem of Wilga. 


\section{Woodlands}

Atalaya hemiglauca low open woodland

Small areas of Atalaya hemiglauca low open woodland (Fig. 5) occur on sandplains in the north of the Mount Murchison block and in the south of the Wilga block. Associated understorey shrubs include Maireana pyramidata, Chenopodium curvispicatum and Atriplex species. Ground layer species include Austrostipa scabra, Brachyscome lineariloba, Daucus glochidiatus, Plantago turrifera and Rhodanthe corymbiflora.

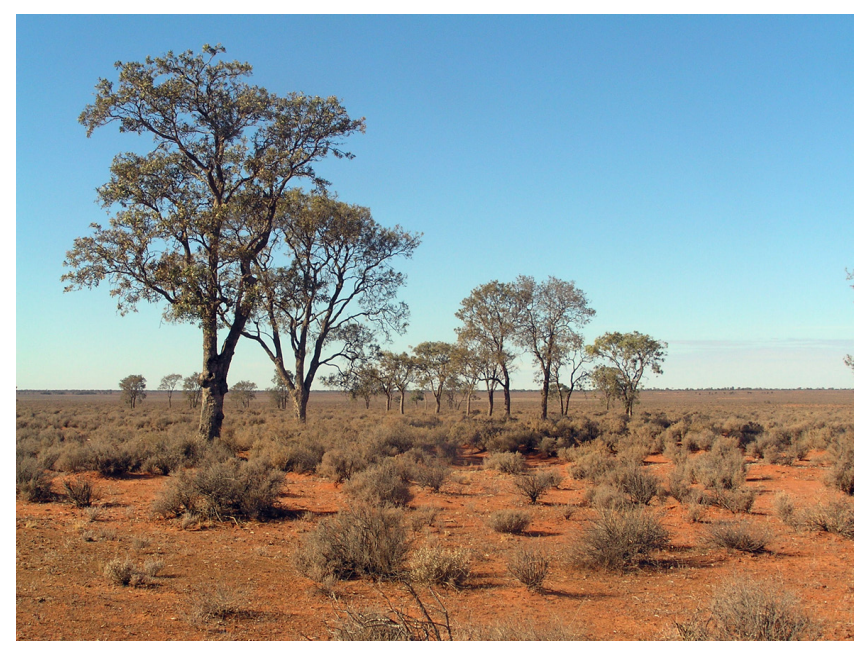

Fig. 5. Atalaya hemiglauca low open woodland

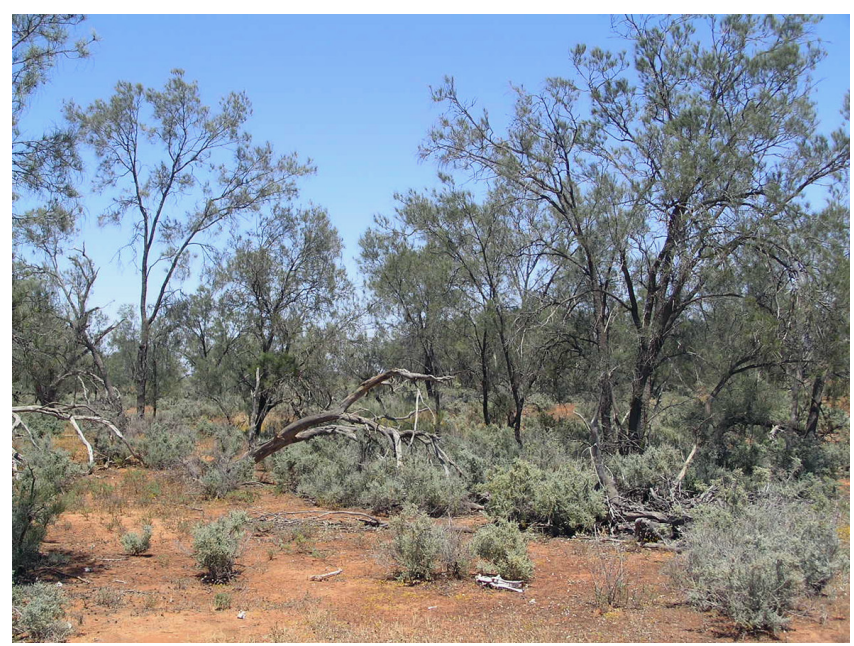

Fig. 6. Casuarina pauper / Alectryon oleifolius subsp. canescens low open woodland

Casuarina pauper / Alectryon oleifolius subsp. canescens low open woodland

Casuarina pauper / Alectryon oleifolius subsp. canescens low open woodland (Fig. 6) growing to 10-12 metres tall occurs on undulating sandplains. Most commonly associated understorey shrubs are Maireana pyramidata, Atriplex holocarpa, Chenopodium curvispicatum, Enchylaena tomentosa and Sclerolaena intricata. Commonly associated ground layer species include Rhodanthe corymbiflora, Gnephosis foliata, Lepidium oxytrichum, Austrostipa scabra and Plantago drummondii.

\section{Eucalyptus camaldulensis open woodland}

Eucalyptus camaldulensis open woodland (Fig. 7) (10 metres tall) occurs in a generally narrow band along the Darling River frontage and some major associated creeks and channels. Common associated trees include Eucalyptus coolabah subsp. coolabah and Acacia stenophylla. Understorey shrub species frequently associated include Enchylaena tomentosa, Chenopodium nitrariaceum and Atriplex leptocarpa. Ground layer species include Einadia nutans, Senecio runcinifolius, Chamaesycce drummondii, Swainsona greyana and Rumex species. Muehlenbeckia florulenta is also frequently associated.

Eucalyptus coolabah / Eucalyptus largiflorens open woodland

Large areas of Eucalyptus coolabah / Eucalyptus largiflorens open woodland (Fig. 8) (10 m tall) occur on heavy soils

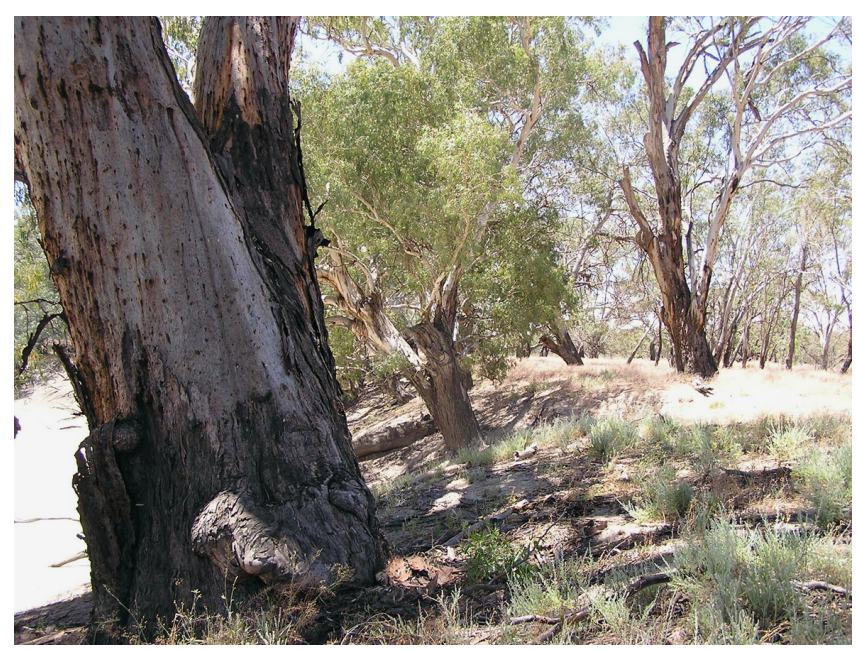

Fig. 7. Eucalyptus camaldulensis open woodland

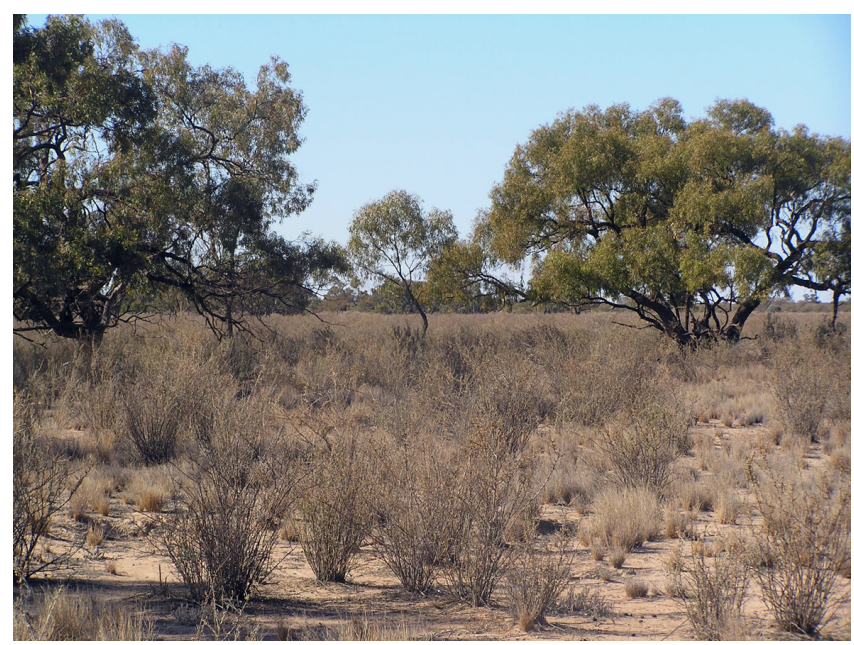

Fig. 8. Eucalyptus coolabah / Eucalyptus largiflorens open woodland 
associated with the Darling River flood plain. Muehlenbeckia florulenta is often present and other frequently associated understorey shrubs include Chenopodium nitrariaceum, Enchylaena tomentosa, Sclerolaena intricata and Sclerolaena muricata. Associated ground layer species include Einadia nutans, Rhodanthe corymbiflora, Plantago turrifera, Plantago drummondii, Pycnosorus pleiocephala and Teucrium racemosum.

Flindersia maculosa low open woodland

Low open woodland dominated by Flindersia maculosa (Fig. 9) occurs on low hills and sandplains. Alectryon oleifolius subsp. canescens is frequently associated. Associated shrubs include Maireana pyramidata, Dissocarpus paradoxus, Enchylaena tomentosa, Atriplex holocarpa, Sclerolaena intricata, Sclerolaena obliquicuspis, Sclerolaena lanicuspis, Salsola kali var. kali and Chenopodium curvispicatum. Ground layer species include Austrostipa scabra, Gnephosis foliata, Tetragonia eremaea, Stenopetalum lineare, Rhodanthe corymbiflora and Vittadinia cuneata.

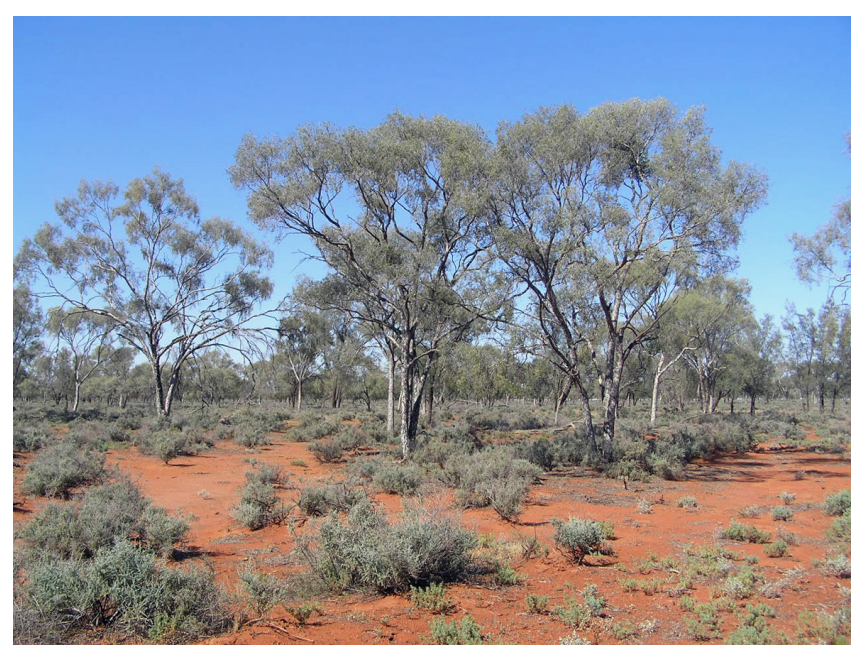

Fig. 9. Flindersia maculosa low open woodland

\section{Tall shrublands}

Acacia aneura tall open shrubland (plains)

Tall open shrubland dominated by Acacia aneura (Fig. 10) frequently occurs on undulating sandplains and low hills. Associated shrubs include Chenopodium curvispicatum, Dissocarpus paradoxa, Dodonaea viscosa subsp. angustifolia, Enchylaena tomentosa and Eremophila sturtii. Ground layer species include Abutilon leucopetalum, Austrostipa nitida, Brachyscome lineariloba, Bulbine alata, Einadia nutans, Eragrostis eriopoda, Erodium crinitum, Gnephosis foliata, Harmsiodoxa brevipes var. brevipes, Ixiolaena tomentosa, Lepidium muelleri-ferdinandii, Lepidium pseudohyssopifolium, Plantago cunninghamii, Pseudognaphalium luteoalbum, Pycnosorus globosus, Rhodanthe corymbiflora, Sida intricata and Solanum esuriale.

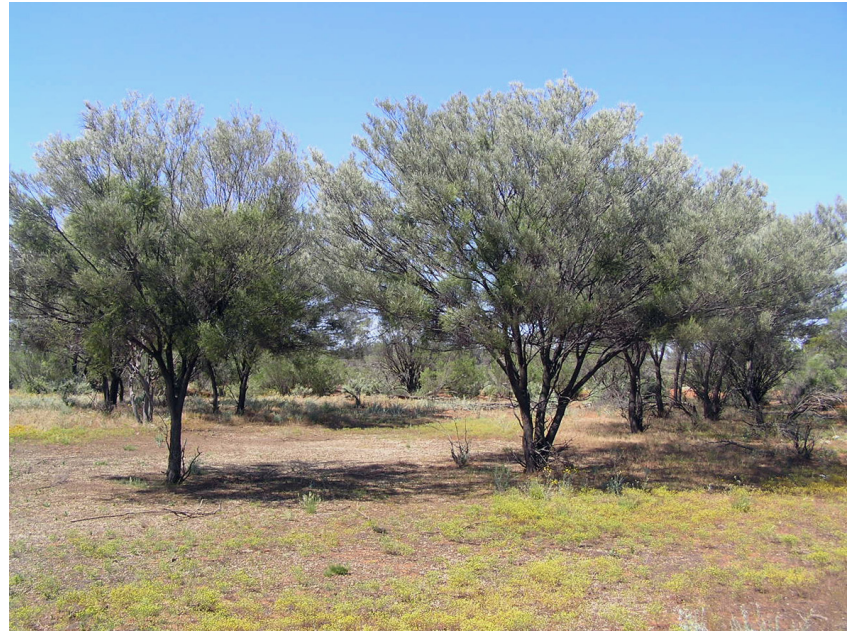

Fig. 10. Acacia aneura tall open shrubland (plains)

Acacia ligulata tall open shrubland

Tall open shrubland dominated by Acacia ligulata (Fig. 11) occurs on deeper sand ridges rising above the plains. Associated shrubs include Enchylaena tomentosa and Salsola kali var. kali. Ground layer species include Sauropus trachyspermus, Myriocephalus stuartii, Crassula colorata and Senecio runcinifolius.

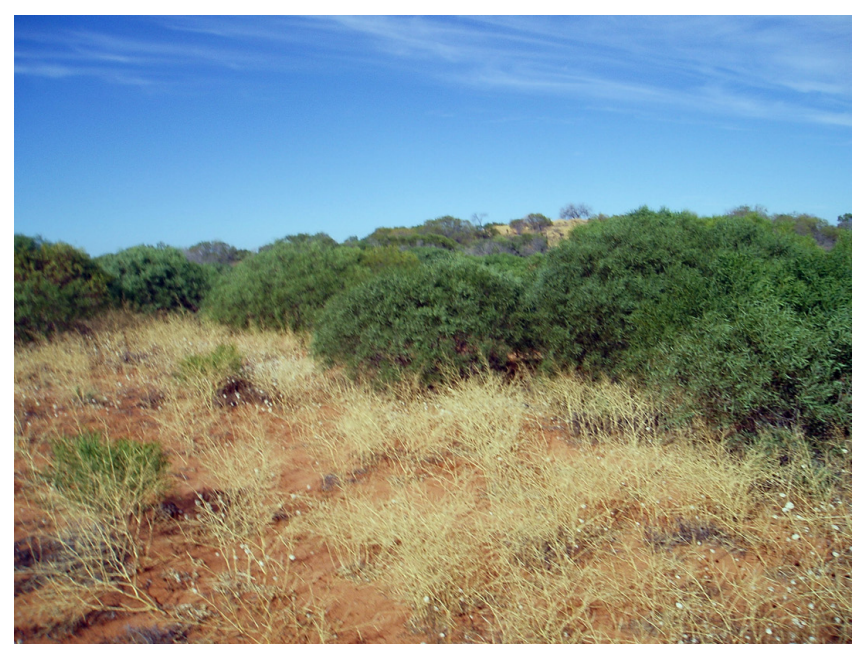

Fig. 11. Acacia ligulata tall open shrubland

\section{Hakea leucoptera tall open shrubland}

Small patches of tall open-shrubland dominated by Hakea leucoptera (Fig. 12) occur on sandplains in the south of the Wilga block. Associated shrub species include Salsola kali var. kali, Sclerolaena bicornis, Sclerolaena intricata, Dodonaea viscosa subsp. angustifolia, Atriplex stipitata and Acacia limbata. Ground layer species include Austrostipa scabra, Rhodanthe corymbiflora, Osteocarpum acropterum, Teucrium racemosum, Plantago drummondii, Sida intricata, Stenopetalum lineare, Pycnosorus pleiocephala and Brachyscome lineariloba. 


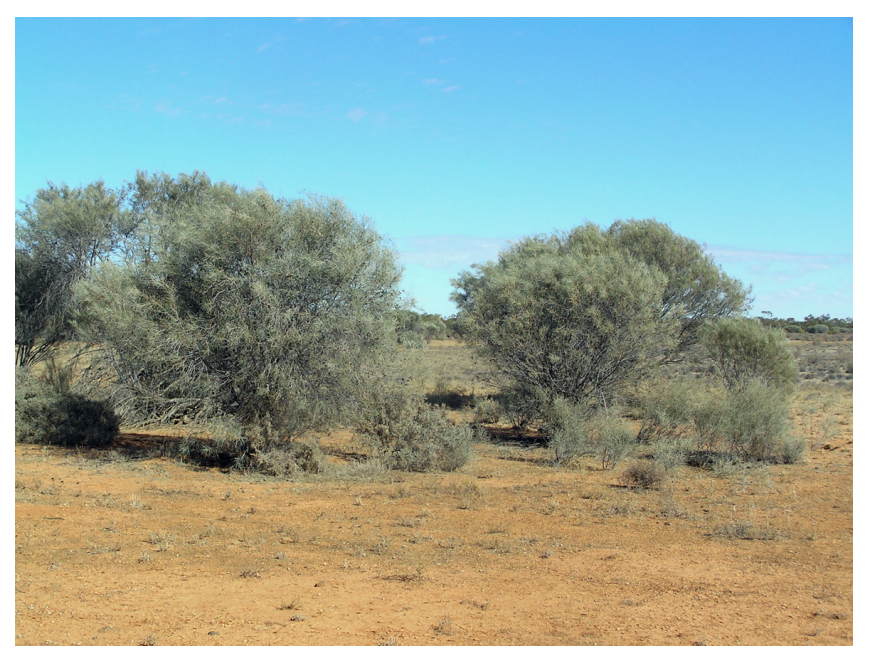

Fig. 12. Hakea leucoptera tall open shrubland

Low shrublands

\section{Acacia victoriae open shrubland}

Acacia victoriae open shrubland (Fig. 13) occurs on sandy rises of the allluvial plains on either side of the Darling River. Associated shrub species include Enchylaena tomentosa, Sclerolaena bicornis var. bicornis, Sclerolaena diacantha and Maireana pyramidata. Ground layer species include Daucus glochidiatus, Myriocephalus stuartii, Rhodanthe corymbiflora, Einadia nutans, Brachyscome lineariloba, Plantago drummondii, Plantago turrifera, Austrostipa scabra, Sida intricata and Pycnosorus pleiocephala.

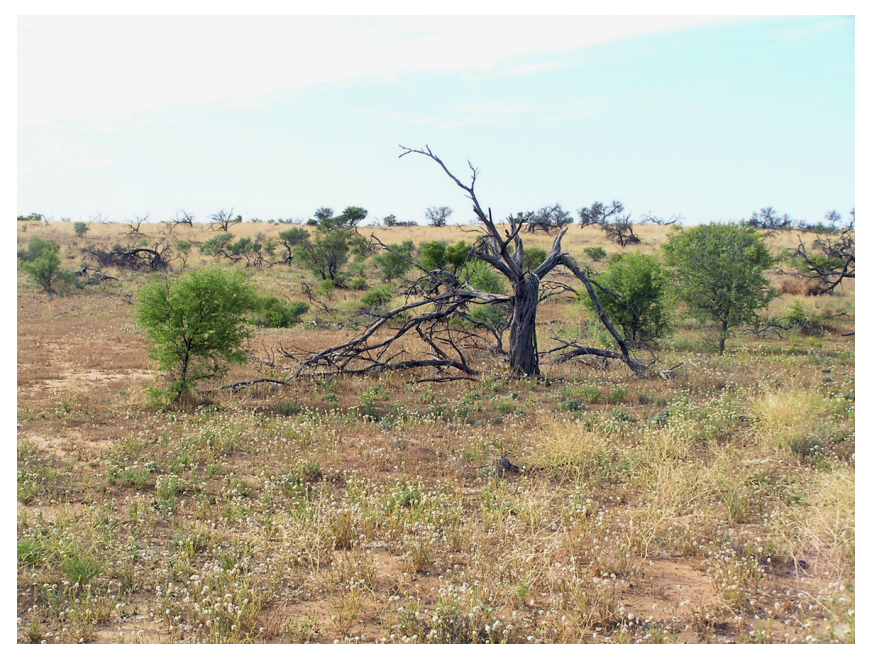

Fig. 13. Acacia victoriae open shrubland

\section{Atriplex nummularia open shrubland}

An open shrub community dominated by Atriplex nummularia (Fig. 14) occurs in the east of the Mount Murchison block on the floodplain of the Paroo River. Associated shrub species include Chenopodium nitrariaceum, Dissocarpus paradoxa, Maireana pyramidata, Sclerolaena obliquicuspis and Sclerolaena patenticuspis. Ground layer species include Rhodanthe corymbiflora, Agrostis avenacea var. avenacea, Atriplex holocarpa, Austrostipa scabra, Centipeda minima, Chamaesyce drummondii, Daucus glochidiatus, Eragrostis australasica, Eragrostis eriopoda, Goodenia pinnatifida, Harmsiodoxa brevipes var. brevipes, Ixiolaena leptolepis, Lepidium pseudohyssopifolium, Marsilea drummondii, Muehlenbeckia florulenta, Osteocarpum acropterum, Plantago cunninghamii, Plantago turrifera, Pycnosorus pleiocephala, Sclerochlamys brachyptera, Stenopetalum lineare and Teucrium racemosum.

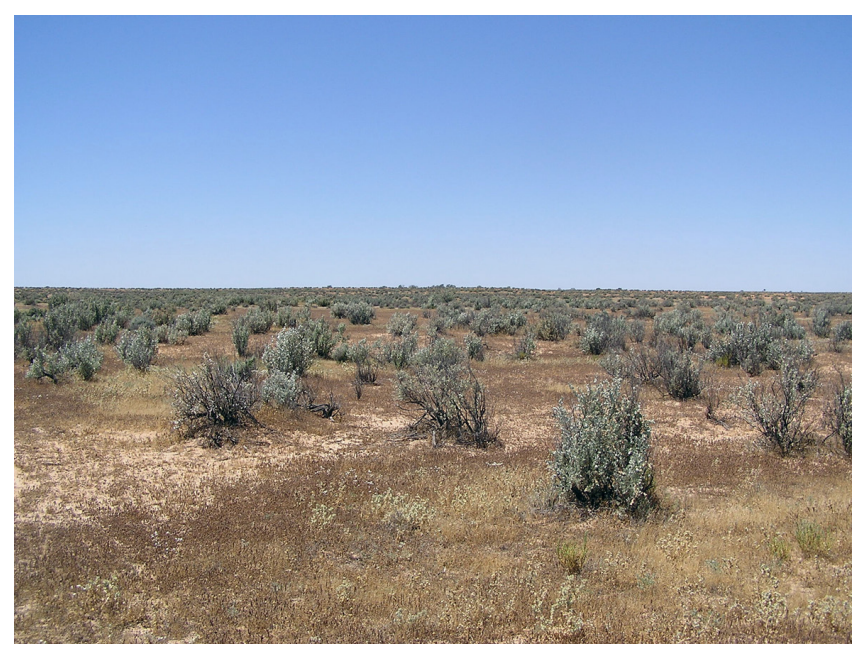

Fig. 14. Atriplex nummularia open shrubland

Eremophila / Dodonaea / Senna open shrubland

This community is commonly associated with Casuarina pauper / Alectryon oleifolius low open woodland. On sandy rises are areas of mixed species shrubland in which Dodonaea viscosa subsp. Angustifolia, Eremophila sturtii and Senna artemisioides are prominent (Fig. 15). Other associated shrubs include Maireana pyramidata, Atriplex stipitata, Sclerolaena diacantha, Sclerolaena intricata, Sclerolaena

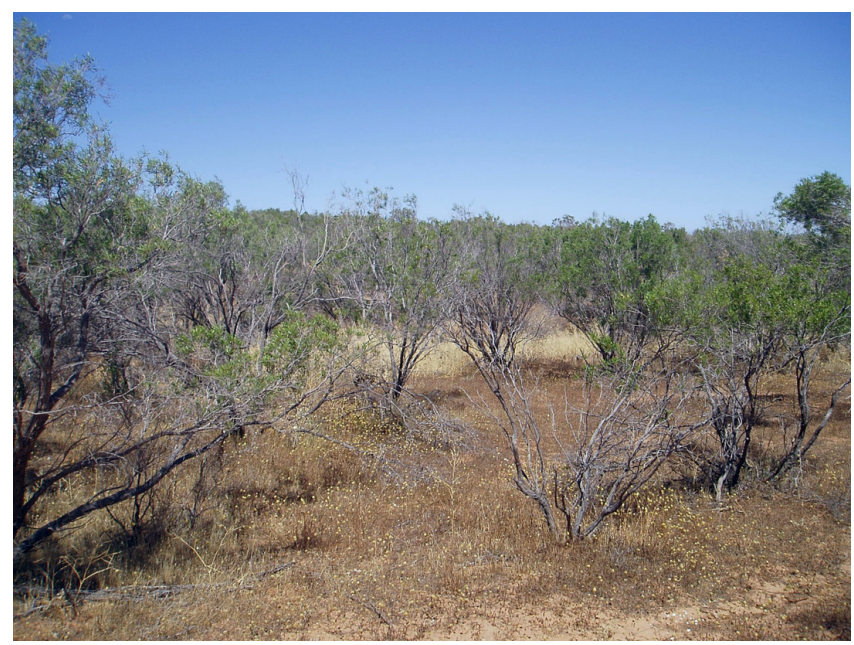

Fig. 15. Eremophila / Dodonaea / Senna open shrubland 
bicornis var. bicornis, Enchylaena tomentosa and Acacia victoriae. Common ground layer associates include Austrostipa scabra, Einadia nutans, Plantago drummondii, Myriocephalus stuartii, Pycnosorus pleiocephala, Brachyscome lineariloba, Goodenia pinnatifida, Teucrium racemosum, Swainsona phacoides, Daucus glochidiatus and Rhodanthe corymbiflora.

\section{Maireana pyramidata low open shrubland}

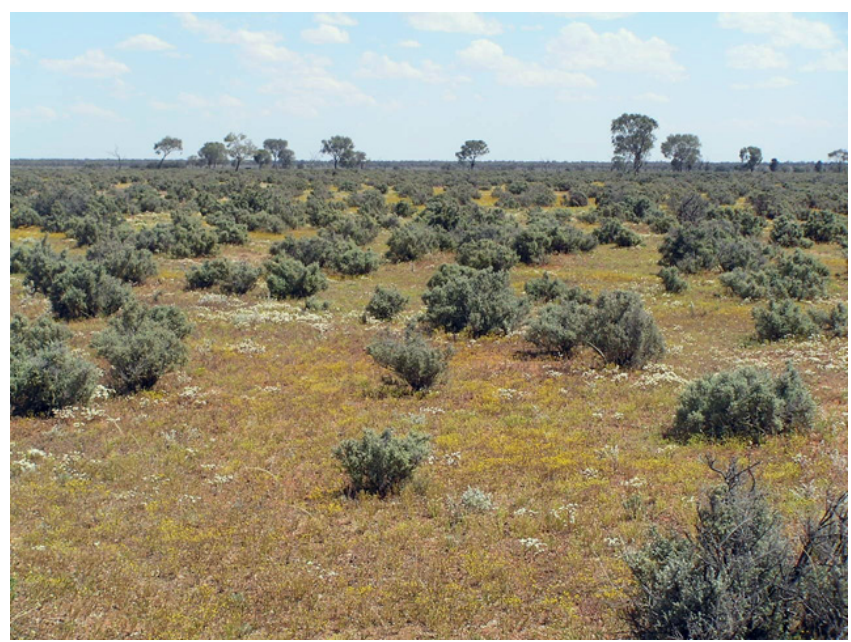

Fig. 16. Maireana pyramidata low open shrubland

A low open shrubland dominated by Maireana pyramidata (Fig. 16) occurs on sandplains and lower slopes of rises. Commonly associated shrubs include Atriplex holocarpa, Dissocarpus paradoxus, Sclerolaena obliquicuspis and Chenopodium curvispicatum. Ground layer species include Rhodanthe corymbiflora, Austrostipa scabra, Pycnosorus pleiocephala, Plantago turrifera, Vittadinia cuneata, Eragrostis eriopoda, Pimelea trichostachya, Brachyscome lineariloba and Tetragonia eremaea.

\section{Muehlenbeckia florulenta open shrubland}

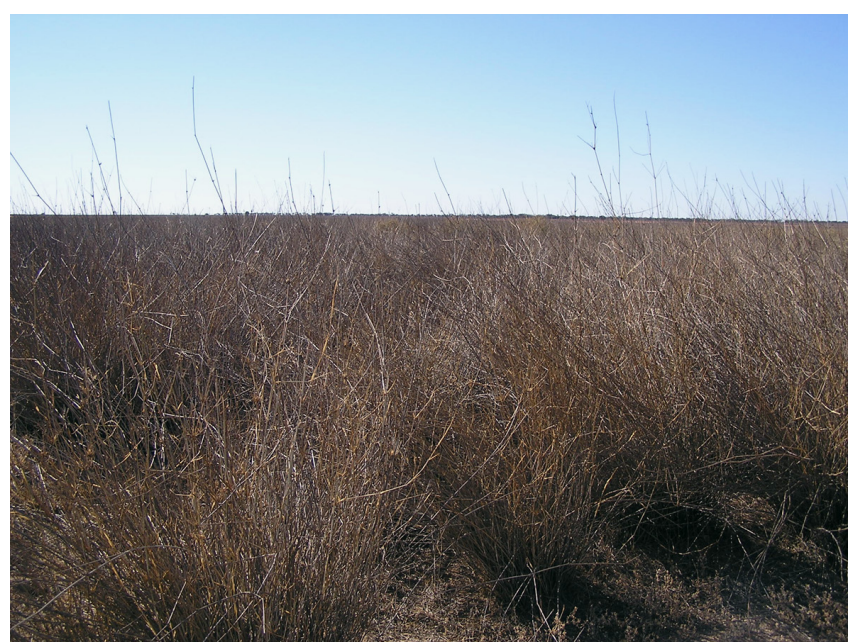

Fig. 17. Muehlenbeckia florulenta open shrubland
Low open shrubland dominated by Muehlenbeckia florulenta (Fig. 17) occurs in low-lying areas associated with the Darling River floodplains and in localised drainage basins. Eragrostis australasica is frequently associated and the community may grade into one dominated by that species. Frequently associated shrubs include Atriplex holocarpa, Sclerolaena muricata and Chenopodium nitrariaceum. Ground layer species include Senecio runcinifolius, Pycnosorus pleiocephala, Rhodanthe corymbiflora, Ixiolaena leptolepis and Agrostis avenacea var. avenacea.

\section{Grasslands}

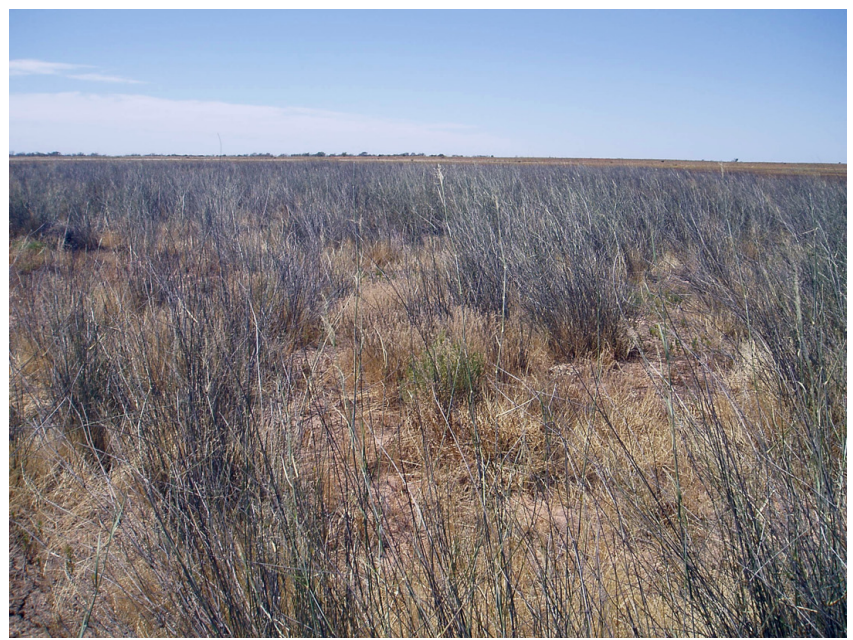

Fig. 18. Eragrostis australasica grassland

\section{Eragrostis australasica grassland}

Areas of Eragrostis australasica grassland (Fig. 18) occur in shallow lakes associated with the Darling River floodplain and in relic lakes within sandplains. Muehlenbeckia florulenta may be associated and other associated species include Agrostis avenacea var. avenacea, Pycnosorus pleiocephala, Plantago drummondii, Chenopodium nitrariaceum, Senecio

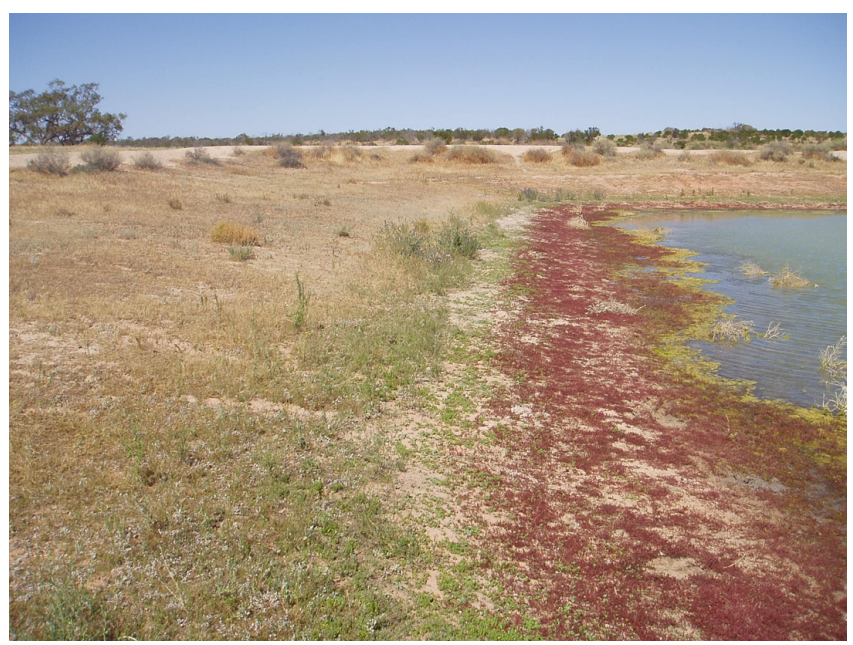

Fig. 19. Anthropogenic herbland 


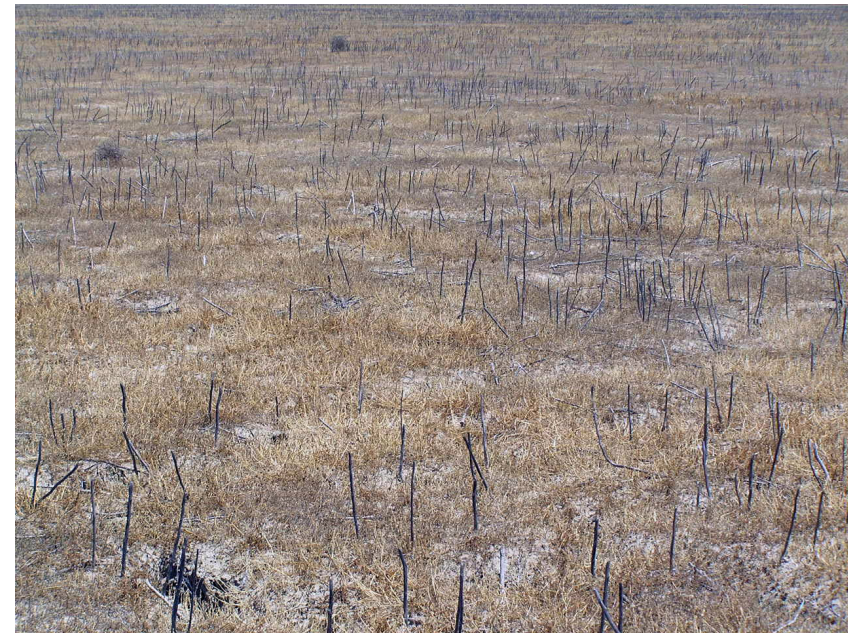

Fig. 20. Cropped lakebed

runcinifolius, Brachyscome lineariloba, Helipterum moschatum, Sclerolaena intricata, Daucus glochidiatus, Eragrostis setifolia, Rumex crystallinus and Marsilea drummondii.

\section{Herblands}

\section{Anthropogenic herbland}

Sites which had been subject to significant disturbance through the pastoral history of the properties, including homestead sites, earth tanks and yards had a predictably, high proportion of weed species (Fig. 19).

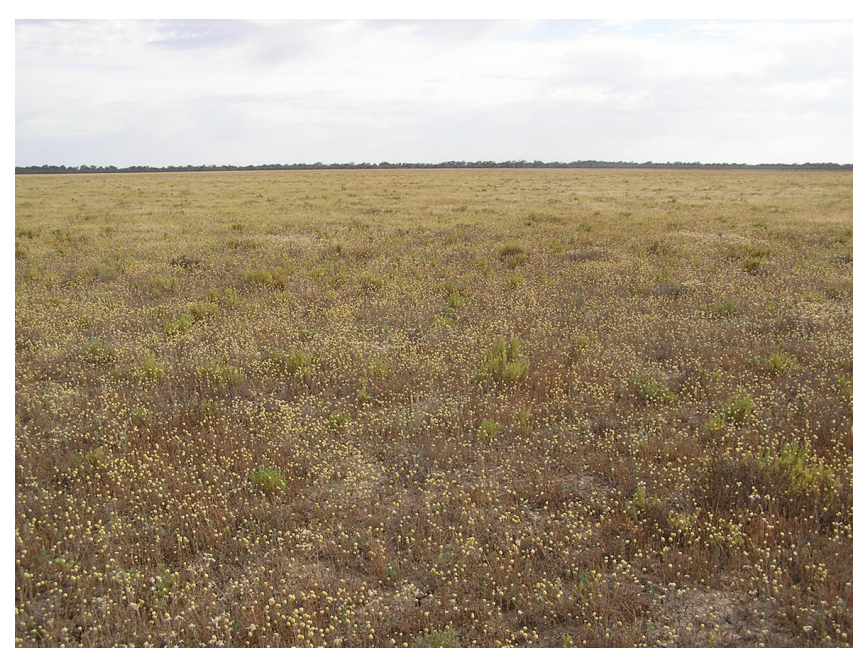

Fig. 21. Lakebed herbland

\section{Cropped lakebed}

Areas of the Darling River floodplain including Wongalara Lake have been cropped in the past. At the time of the survey there was little distinguishable vegetation on most of these areas apart from crop residues (Fig. 20). The bed of Lake Poopelloe, which should typically be vegetated by a Muehlenbeckia florulenta open shrubland supports remnants of a Safflower (Carthamus tinctorius) crop.

\section{Lakebed herbland}

As the lakes dry out after flooding an annual herbland develops (Fig. 21). This is dominated by Marsilea drummondii, Centipeda minima, Heliotropium species,

Table 4. Sampling intensity, species richness and weediness of vegetation communities of the Mount Murchison and Wilga areas.

\section{Vegetation community}

\section{Woodlands}

Atalaya hemiglauca low open woodland

Casuarina pauper / Alectryon oleifolius low open woodland

Eucalyptus camaldulensis open woodland

Eucalyptus coolabah / Eucalyptus largiflorens open woodland

Flindersia maculosa low open woodland

Tall shrublands

Acacia aneura tall open shrubland (plains)

Acacia ligulata tall open shrubland

Hakea leucoptera tall open shrubland

Low shrublands

Acacia victoriae open shrubland

Atriplex nummularia open shrubland

Eremophila / Dodonaea open shrubland

Maireana pyramidata low open shrubland

Muehlenbeckia florulenta open shrubland

Grasslands

Eragrostis australasica grassland

No. of quads.

Native species richness
Introduced species richness

Mean Total

\section{Herblands}

Anthropogenic herbland

Cropped lakebed

Lakebed herbland

42
46
42
95
65

$\begin{array}{lll}59 & 3.8 & 12 \\ 34 & 1.3 & 4 \\ 52 & 3.8 & 9 \\ 77 & 1.8 & 10 \\ 77 & 3.1 & 16\end{array}$


Myriophyllum verrucosum, Plantago turrifera, Sclerolaena intricata and Pycnosorus pleiocephala. It is likely that the species composition of these areas is variable and dependant on seasonality of rainfall events, with grasses becoming more prominent following good summer rainfall.

\section{Plant species}

A total of 237 vascular plant species from 46 families were recorded during this study of the Mount Murchison and Wilga areas (Appendix 1). Of the plant species recorded from the Park, $37(15.6 \%)$ are introduced. The sampling effort in each vegetation community, mean and total native and introduced species richness is shown in Table 4.

\section{Discussion}

\section{Mapping communities}

There are a number of inherent problems in vegetation mapping: vegetation mapping assumes discontinuities between communities which may not exist; the constraints of cartography determine the minimum area that can clearly be distinguished; it is generally not feasible to ground truth the whole of an area and thus parts of the map assume a consistent relationship between the vegetation and other features such as soil type and topography.

Beadle's (1948) map of western NSW at approximately 1:1 000000 scale includes two units for the area. James's (1960) map of the Paroo-Upper Darling shows three vegetation units and Milthorpe (1991) 1:500 000 map of north western NSW shows five units. Pickard and Norris's (1994) map of northwestern NSW shows nine vegetation units. In the attached map at 1:50 000 scale, 16 units are mapped and a further one indicated by point location (Anthropogenic herbland). It was difficult to separate the shrubland communities of the Popelloe landsystem of Wilga. The map suffers from the limitations noted above. The smallest area that could be mapped was 100 metres in width but in the interest of clarity some vegetation types occurring in narrow bands, such as Eucalyptus camaldulensis along the Darling River were exaggerated to this width. Similarly some areas remote from tracks may include small patches of another vegetation unit from that mapped.

During the survey over $330 \mathrm{~km}$ of driven and walked transects were traversed and, given the association of many vegetation communities with landscape features, boundaries could be drawn with some confidence. With the current technology of mapping enabling changes to be readily incorporated, it is hoped that the map will be refined with following further botanical survey.

Table 5. Conservation status of communities based on Benson et al. (2010)

\section{Vegetation community}

Woodlands

Atalaya hemiglauca low open woodland

Casuarina pauper / Alectryon oleifolius low open woodland

Eucalyptus camaldulensis open woodland

Eucalyptus coolabah / Eucalyptus largiflorens open woodland

\section{Flindersia maculosa low open woodland}

Tall shrublands

Acacia aneura tall open shrubland (plains)

Acacia ligulata tall open shrubland

Hakea leucoptera tall open shrubland

Low shrublands

Acacia victoriae open shrubland

Atriplex nummularia open shrubland

Eremophila / Dodonaea open shrubland

Maireana pyramidata low open shrublan

Muehlenbeckia florulenta open shrubland

Grasslands

Eragrostis australasica hummock grassland

Herblands

Anthropogenic herbland

Lakebed herbland

\section{Area (ha) Equivalent Benson et approx al. (2010) vegetation community I.D}

457

1,284

491

13,147

137
58
36
$37,38,40$

\section{9,997}

383

1,098

24

2,658

518

4,604

16,785

24,001

483
Conservation status (Benson et al. 2010)

Near Threatened

Near Threatened

Vulnerable

Vulnerable (ID 37), Least Concern (ID 38), Endangered (ID 40). Listed as Endangered under the NSW Threatened Species Conservation Act 1995 and Commonwealth Environment Protection and Biodiversity

Conservation Act 1999

Near Threatened

Near Threatened

Least Concern

Near Threatened

Vulnerable

Endangered

Least Concern

Near Threatened

Least Concern

Least Concern

N/A

Least Concern 


\section{Distribution of communities}

Floristically, the Mount Murchison and Wilga areas could be considered contiguous if not separated by the Darling River.

The distribution and species composition of vegetation communities within Paroo Darling National Park is largely determined by variation in topography, landform position and soil type. Eucalyptus species open woodlands are associated with texture contrast soils of the major creeklines and on clays around the overflow lakes. Woodlands variously dominated by Casuarina pauper and Flindersia maculosa occur on desert loams and mixed herblands occur on the clays associated with the floodplains of the Darling River. Maireana pyramidata low open shrubland occurs on the sandplains. Other factors, notably past grazing history, have also played a role in determining the present distribution and floristic composition of the communities present.

\section{Vegetation condition}

Whilst this was not intended to be a detailed assessment of vegetation condition, regeneration of overstorey and perennial understorey species was noted. Species richness and weediness are additional factors which give some measure of vegetation condition. The communities of the Mount Murchison area are overall in good condition despite the history of grazing management. It suggests that this part of the Park has previously been subject to a relatively conservative grazing regime. Grazing pressure for the Wilga area appeared to be elevated towards the homestead and holding paddocks, however it is moderate to low over much of the remaining area.

\section{Conservation status of vegetation communities}

The communities mapped largely correspond to those listed by Benson (1989), Benson (2006), Benson (2008) and Benson et al. (2010). Table 5 shows the threat category of communities based on Benson et al. (2010). Nine of the communities recorded have a threat category of Near Threatened, Vulnerable or Endangered. Benson et al. (2010) has allocated threatened categories which are based on a number of sources including the guidelines for nominating ecological communities under the Commonwealth EPBC Act (Benson 2006).

Eucalyptus coolabah / Eucalyptus largiflorens open woodland is listed as an endangered ecological community under the Commonwealth Environment Protection and Biodiversity Conservation Act 1999 (EPBC Act) and the NSW Threatened Species Conservation Act 1995 (TSC Act). Under the EPBC Act, the community is referred to as Coolibah - Black Box Woodlands of the Darling Riverine Plains and the Brigalow Belt South Bioregions and under the TSC Act, the community is referred to as Coolibah-Black Box Woodland in the Darling Riverine Plains, Brigalow Belt South, Cobar Peneplain and Mulga Lands Bioregion. This endangered ecological community is known to be associated with the following Benson et al. (2010) vegetation communities:
Black Box woodland on NSW central and northern floodplains including the DRP and BBS Bioregions (ID No. 37);

Coolabah - River Coobah - Lignum woodland of frequently flooded floodplains mainly in the Darling Riverine Plains Bioregion (ID No. 39); and

Coolabah open woodland with chenopod/grassy ground cover on grey and brown clay floodplains (ID No. 40).

The Benson et al. (2010) threat categories for these vegetation communities associated with the endangered ecological community are outlined in Table 5. Keith et al. (2009) determined that around $60 \%$ of the community had been lost since European settlement and that the rate of loss had increased in recent years. That which remains is increasingly fragmented (NFRPC 2004). Further to clearing other key threats to the endangered ecological community include hydrological changes and altered water flow and flooding regimes (including inundation duration), inappropriate grazing regimes and invasion by weeds (Benson 2006; Benson 2008; Benson et al. 2010; TSSC 2011; Keith et al. 2009). A major threat to the Eucalyptus camaldulensis open woodland community, a related floodplain community, has been and continues to be also a reduction in flooding regimes (Benson 2006; Benson 2008; Benson et al. 2010).

Almost all of the communities recorded for Mount Murchison and Wilga are susceptible to and threatened by grazing pressure (Benson 2006; Benson 2008; Benson et al. 2010). Grazing threatens the regeneration of many palatable plant species associated with these communities which ultimately alters the floristic diversity and structure of the community (Benson 2006; Benson 2008; Benson et al. 2010). There is general concern for communities such as Casuarina pauper / Alectryon oleifolius low open woodland (Westbrooke 2005; Benson 2006), Hakea leucoptera tall open shrubland (Westbrooke 1998),Atalaya hemiglauca low open woodland, , Eucalyptus coolabah / E. largiflorens open woodland, Acacia aneura tall open shrubland, and Acacia ligulata tall open shrubland occurs (Benson 2006; Benson 2008; Benson et al. 2010)and for example where key species may die off unless recruitment. A number of these woodland communities such as Atalaya hemiglauca low open woodland, Casuarina pauper / Alectryon oleifolius low open woodland, Flindersia maculosa low open woodland and Hakea leucoptera tall open shrubland are regarded as near threatened largely due to past timber harvesting/ thinning/clearing and lack of regeneration (Benson et al. 2010). Atalaya hemiglauca low open woodland may become vulnerable if recruitment of key species does not occur (Benson et al. 2010). Acacia victoriae open shrubland is likely to be a derived community as a result of the Callitris being removed in the past from timber cutting (Benson et al. 2010). Callitris glaucophylla seedlings are known to be intolerant of grazing, palatable and very slow growing in the early stages (Westbrooke 1998) which may partly explain why following this disturbance, there is a lack of recruitment and a gradual loss of this species from this community. 
Atriplex nummularia open shrubland is considered endangered (Benson et al. 2010) however the formal status of this community remains unresolved in NSW.. The presence of these vegetation communities on Mount Murchison and Wilga areas of Paroo-Darling National Park has made a significant contribution to conservation of plant communities in NSW.

\section{Plant species}

Two hundred and thirty seven species of vascular plants were recorded during this study. As noted, this survey, undertaken following three years of severe drought, whilst the winter rains meant that a range of herbs and grass were recorded, it is likely that many more species are still to be recorded.

The highest representation of these species recorded for the Mount Murchison and Wilga areas was from the family Chenopodiaceae (45).

The highest levels of occurrence of introduced species were in communities subject to the greatest influence from water and disturbance. These include the Anthropogenic herblands around earth tanks. This is in accord with Westbrooke (1990) who found a high negative correlation between occurrence of introduced species and distance from water in studies at Mallee Cliffs National Park and Nanya Station.

\section{Rare, threatened or restricted species}

None of the species recorded during this study are listed under the Environment Protection and Biodiversity Conservation Act 1999 (Cwlth) or the Threatened Species Conservation Act 1995 (NSW).

\section{Conclusion}

The Mount Murchison and Wilga blocks of Paroo Darling National Park are a significant component of the New South Wales Park estate. The area is important for protecting a range of vegetation communities which are under threat from continued rangeland grazing in unprotected areas. This study provides valuable baseline data to aid park managers in prioritising actions to facilitate the recovery of the vegetation from past use and the protection of biodiversity values.

\section{Acknowledgements}

This work was carried out under the conditions of Licence S10283 of the New South Wales National Parks and Wildlife Service (NSW NPWS). We acknowledge the support of the NSW NPWS in the conduct of this survey, in particular Paul Burton for his hospitality and friendship. We would also like to thank Singarayer Florentine, Kate Callister, Grant Palmer, Sara Munawar, Andrew Warnock and Rosie Grundell for their assistance with the field survey and Janet Leversha for assistance throughout the project.

\section{References}

Beadle, N.C.W. (1945). Vegetation Map of Western New South Wales. Soil Conservation Service, Sydney.

Beadle, N.C.W. (1948). The Vegetation and Pastures of Western New South Wales with Special Reference to Soil Erosion. Government Printer, Sydney.

Benson, J. (1989). Establishing priorities for the conservation of rare or threatened plants and plant associations in New South Wales. In: The Conservation of Threatened Species and Their Habitats - Occasional Paper No. 2: 17-82. Eds. M. Hicks and P. Eiser. Australian Committee for IUCN, Canberra.

Benson, J. S. (2006) New South Wales vegetation classification and assessment: Introduction - the classification, database, assessment of protected areas and threat status of plant communities. Cunninghamia 9(3): 331-382.

Benson, J. S., Allen, C. B., Togher, C. and Lemmon, J. (2006) New South Wales vegetation classification and assessment: Part 1 plant communities of the NSW Western Plains. Cunninghamia 9(3): 383- 450.

Benson, J. (2008). New South Wales Vegetation classification and Assessment: Part 2 Plant communities of the NSW Southwestern Slopes Bioregion and update of NSW Western Plains plant communities, Version 2 of the NSWVCA database. Cunninghamia, 10(4): 599-673.

Benson, J.S., Richards, P., Waller, S. and Allen, C. (2010). New South Wales Vegetation classification and Assessment: Part 3 Plant communities of the NSW Brigalow Belt South, Nandewar and west New England Bioregions and update of NSW Western Plains and South-western Slopes plant communities, Version 3 of the NSWVCA database. Cunninghamia 11(4).

Clewett, J. F., Clarkson, N. M., Owens, D. T. and Abrecht, D. G. (1994). Australian Rainman: Rainfall Information for Better Management. Department of Primary Industries, Brisbane.

Edwards, K. (1979). Rainfall in New South Wales - With Special Reference to Soil Conservation - Technical Handbook No. 3. Soil Conservation Service of New South Wales, Sydney.

Hardy, B. (1969). West of the Darling. Rigby, Adelaide.

Hazelton, P. (1977). Wilcannia Land Systems Series Sheet SH 5416. New South Wales, Soil Conservation Service.

Heathcote, R. L. (1965). Back of Bourke: A Study of Land Appraisal and Settlement in Semi-arid Australia. Melbourne University Press, Carlton.

Hercus, L. (1993). Paakantyi Dictionary. Published with the assistance of AIATSIS, Canberra.

Hope, J. and Lindsay, R. (2010). The people of the Paroo River. Department of Environment, Climate Change and Water NSW, Sydney.

Hunter, J. and Fallavollita, E. (2003). Vegetation and Floristics of Paroo Darling National Park - Thilta Karra Section. Report to the New South Wales National Parks and Wildlife Service.

James, J. W. (1960). Erosion survey of the Paroo-Upper Darling region. Part III. Journal of Soil Conservation Service of NSW 16: $185-206$.

Jervis, J. (1948). The west Darling country: its exploration and development. Royal Australian Historical Society 34: 65-88.

Kershaw, K. A. and Looney, J. H. H. (1985). Quantitative and Dynamic Plant Ecology. Edward Arnold, Caufield East, Victoria.

Keith DA, Orscheg C, Simpson CC, Clarke PJ, Hughes L, Kennelly SJ, Major RE, Soderquist TR, Wilson AL, Bedward M (2009) A new approach and case study for estimating extent and rates of habitat loss for ecological communities. Biological Conservation 142, 1469-1479.

Knight, R. (1994). Flora, Fauna and Wilderness Values of the Mount Glass and Peery Lake areas, Western New South Wales. Report by the Wilderness Society to the Australian Heritage Commission, Sydney. 
Lembit, R. (1993). NSW Wilderness Review Stage II - Wilderness Area Investigation, Peery Lake and Mount Glass Study Areas - Botanical Survey Report. Report to the Wilderness Society, Sydney.

Milthorpe, P. L. (1991). Vegetation. In: Lands of the North-West Corner of NSW - Technical Report No. 12. Ed. P.L. Milthorpe, Soil Conservation Service of NSW.

NFRPC, (2004). Vegetation Communities of the Northern Floodplains Western New South Wales Books 1-3: Walgett, Brewarrinna and Bourke Shires. Northern Floodplains Regional Planning Committee.

NPWS (2000). File F/2835/vol. III - Peery. New South Wales National Parks and Wildlife Service.

NPWS (2002). File 02-00269. New South Wales National Parks and Wildlife Service.

Pickard, J. and Norris, E. H. (1994). The natural vegetation of north-western New South Wales: notes to accompany the 1:1 000000 vegetation map sheet. Cunninghamia 3(3): 423-464.

Pickard, J. (1990). Analysis of stocking records from 1884 to 1988 during the subdivision of Momba, the largest property in semiarid New South Wales. Proceedings of the Ecological Society of Australia 16: 245-253.

Specht, R. L. (1970). Vegetation. In: The Australian Environment. Ed. G. W. Leeper. Melbourne University Press, Melbourne.

Stanley, R. J. (1991). Land settlement and development. In: Lands of the North-West Corner of NSW - Technical Report No. 12. Ed. P. L. Milthorpe. Soil Conservation Service of NSW.

TSSC (2011). Conservation advice for the Coolibah - Black Box Woodlands of the Darling Riverine Plains and the Brigalow Belt South Bioregions ecological community. Threatened Species Scientific Committee.

Walker, P. (1972). Barnato Land Systems Series Sheet SH 55-13. New South Wales, Soil Conservation Service.

Westbrooke, M. E. (1990). Effects of grazing pressure on weediness in mallee communities: studies at Mallee Cliffs National Park and Nanya Station, south-western New South Wales. In: The Mallee Lands: A Conservation Perspective. Eds J. C. Noble, P. J. Joss and G.K. Jones. CSIRO, Melbourne.
Westbrooke, M. E. (1998). The ecology and regeneration status of Belah woodlands in south-eastern Australia. PhD Thesis. Department of Botany. School of Life Sciences. Faculty of Science, Technology and Engineering. LaTrobe University. Bundoora, Victoria.

Westbrooke, M.E. (2005). Relationship between perennial species richness and distance from water in Casuarina pauper (Belah) woodland. Victorian Naturalist, 122: 57-62

Westbrooke, M., Gowans, S. and Gibson, M. (2011). The vegetation of the Coonavitra area, Paroo Darling National Park, western New South Wales. Cunninghamia 12 (1): 7-27.

Westbrooke, M., Gowans, S., Gibson, M., Callister, K., Palmer, G., Florentine, S., O'Keefe, M., Warnock, A. and Grundell, R. (2006a). The Vegetation of the Coonavitra area, Paroo Darling National Park, Western New South Wales. Report prepared for the New South Wales National Parks and Wildlife Service by the Centre for Environmental Management, University of Ballarat.

Westbrooke, M., Gowans, S., Gibson, M., Callister, K., Palmer, G., Florentine, S., O'Keefe, M., Warnock, A. and Grundell, R. (2006b). The Vegetation of the Mount Murchison and Wilga areas, Paroo Darling National Park, Western New South Wales. Report prepared for the New South Wales National Parks and Wildlife Service by the Centre for Environmental Management, University of Ballarat.

Westbrooke, M., Leversha, J., Gibson, M., Milne, R., Gowans, S., Harding, C., Callister, K. and O'Keefe, M. (2002). The Vegetation of Peery National Park Western New South Wales. Report prepared for the New South Wales National Parks and Wildlife Service by the Centre for Environmental Management, University of Ballarat, Victoria.

Westbrooke, M., Leversha, J., Gibson, M., O’Keefe, M., Milne, R., Gowans, S., Harding, C. and Callister, K. (2003). The vegetation of Peery Lake area, Paroo-Darling National Park, western New South Wales. Cunninhamia 8(1): 111-128.

Young, M.D., Gibbs, M., Holmes, W.E. and Mills, D.M.D. (1984). Socio-economic influences on pastoral management. In: Harrington, G.M., Wilson, A.D. and Young, M.D. eds. Management of Australia's Rangelands. CSIRO, Melbourne.

Manuscript accepted 19 October 2012 
Appendix 1. Flora species recorded within the Mount Murchison and Wilga areas with frequency (\%) of occurrence in communities

Nomenclature is according to Harden (1990-1993). * denotes introduced species.

\section{Vegetation communities}

\section{Woodlands}

1 Atalaya hemiglauca open woodland

2 Casuarina pauper / Alectryon oleifolius low open woodland

3 Eucalyptus camaldulensis open woodland

4 Eucalyptus coolabah / Eucalyptus largiflorens open woodland

5 Flindersia maculosa low open woodland

\section{Tall shrublands}

6 Acacia aneura tall open shrubland (plains)

7 Acacia ligulata tall open shrubland

8 Hakea leucoptera tall open shrubland

\section{Low Shrublands}

9 Acacia victoriae open shrubland

10 Atriplex nummularia open shrubland

11 Eremophila / Dodonaea open shrubland

12 Maireana pyramidata low open shrubland

13 Muehlenbeckia florulenta open shrubland

\section{Grasslands}

14 Eragrostis australasica hummock grassland

\section{Herblands}

15 Anthropogenic herbland

16 Cropped lakebed

17 Lakebed herbland

Taxon, family and name

Number of quadrats

Vegetation communities

$\begin{array}{lllllllllllllllll}1 & 2 & 3 & 4 & 5 & 6 & 7 & 8 & 9 & 10 & 11 & 12 & 13 & 14 & 15 & 16 & 17 \\ 3 & 3 & 7 & 21 & 9 & 1 & 1 & 1 & 5 & 3 & 4 & 10 & 18 & 5 & 3 & 2 & 6\end{array}$

\section{FERNS}

Marsileaceae

Marsilea drummondii

$\begin{array}{llllll}3 & 3 & 7 & 21 & 9 & 1\end{array}$

Marsilea spp.

10

100

$20 \quad 33$

$17 \quad 40$

\section{MONOCOTYLEDONS}

Amaryllidaceae

Crinum flaccidum

\section{Asphodelaceae}

Bulbine alata

Bulbine bulbosa

Bulbine spp.

Cyperaceae

Isolepis congrua

Isolepis spp.

\section{Poaceae}

Agrostis avenacea var. avenacea

Austrostipa nitida

Austrostipa nodosa

Austrostipa scabra

Austrostipa spp.

$\begin{array}{ccccc} & 33 & 5 & & \\ & & & 11 & 100 \\ 100 & 67 & 5 & & \\ & & & 5 & 100 \\ & & & 11 & \end{array}$

33

$\begin{array}{ccc}5 & & 100 \\ 10 & 22 & \end{array}$

20 33
33

10
10

$\begin{array}{ccccccc} & 20 & 33 & & & 33 \\ & & & & & 6 \\ 100 & 60 & 33 & 100 & 90 & 11 \\ & 20 & & & & 6\end{array}$

$80 \quad 33$ 
Taxon, family and name Number of quadrats

* Xanthium spinosum

Boraginaceae

* Echium plantagineum Heliotropium europaeum Heliotropium spp.

* Heliotropium supinum

Omphalolappula concava

Brassicaceae

* Alyssum linifolium

Arabidella trisecta

* Brassica spp.

* Brassica tournefortii

* Carrichtera annua

Harmsiodoxa blennodioides

Harmsiodoxa brevipes var. brevipes

Lepidium hyssopifolium

Lepidium muelleri-ferdinandii

Lepidium oxytrichum

Lepidium papillosum

Lepidium pseudohyssopifolium

Lepidium spp.

* Sisymbrium erysimoides

* Sisymbrium irio

Stenopetalum lineare

Caesalpiniaceae

Senna form taxon 'artemisioides'

Senna form taxon 'filifolia'

Senna form taxon 'petiolaris'

Senna form taxon 'zygophylla'

Campanulaceae

Wahlenbergia communis

Wahlenbergia gracilis

Wahlenbergia spp.

Caryophyllaceae

* Spergularia rubra

Casuarinaceae

Casuarina pauper

Chenopodiaceae

Atriplex angulata

Atriplex eardleyae

Atriplex holocarpa

Atriplex leptocarpa

Atriplex limbata

Atriplex lindleyi

Atriplex nummularia

Atriplex pseudocampanulata

Atriplex semibaccata

Atriplex spp.

Atriplex stipitata

Chenopodium auricomum

Chenopodium cristatum

Chenopodium curvispicatum

Chenopodium desertorum

Chenopodium melanocarpum

* Chenopodium murale

Chenopodium nitrariaceum

Chenopodium pumilio

Chenopodium spp.

Dissocarpus paradoxus

Einadia nutans

Enchylaena tomentosa

Maireana appressa

Maireana brevifolia

Maireana coronata

Maireana lobiflora

Maireana pyramidata

Maireana spp.

Osteocarpum acropterum

Rhagodia spinescens

Salsola kali var. kali

Salsola kali var. strobilifera

Sclerochlamys brachyptera

Sclerochlamys spp.
Vegetation communities

$\begin{array}{ccccccccccccccccc}1 & 2 & 3 & 4 & 5 & 6 & 7 & 8 & 9 & 10 & 11 & 12 & 13 & 14 & 15 & 16 & 17 \\ 3 & 3 & 7 & 21 & 9 & 1 & 1 & 1 & 5 & 3 & 4 & 10 & 18 & 5 & 3 & 2 & 6\end{array}$

$\begin{array}{cccccc} & & & 10 & 33 & \\ & 33 & & & & 100 \\ 33 & & 29 & 24 & & \\ 33 & & & 14 & & \\ 33 & & & & & \\ & & & & 11 & 100 \\ & & & 10 & & 100 \\ 33 & 67 & & & & \\ & & & 5 & 11 & \\ & 33 & 14 & 14 & & 100 \\ 33 & 67 & 14 & 14 & & \\ & & & 51 & 44 & \\ & & & & 67 & \end{array}$

100<smiles></smiles>

10

100

$\begin{array}{lll}20 & 56 & 20 \\ 10 & & 20\end{array}$

50

$100 \quad 100 \quad 80$

$\begin{array}{ccccc}100 & & 28 & & 100 \\ & 10 & 6 & & 33\end{array}$

$20 \quad 33 \quad 25$

$\begin{array}{cccccccc} & & & & 10 & & & 33 \\ & & & 25 & & & & 33 \\ & & 33 & & 10 & 17 & 20 & 67 \\ 100 & 20 & 33 & 25 & 10 & 50 & 20 & 100 \\ & 20 & & & & 6 & & 33 \\ 100 & & 33 & & 30 & & & \end{array}$

25

25
50

100

22

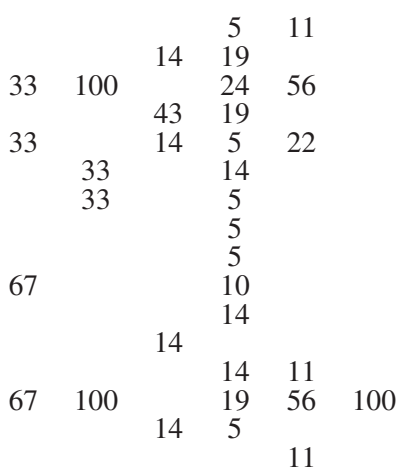

20

20

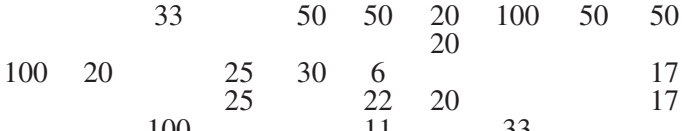

$100 \quad 20$

$$
6
$$

75

33

40

1720

20

67

33

$71 \quad 67$

11

$\begin{array}{llllll} & & 14 & 14 & 67 & 100 \\ 33 & 33 & 71 & 67 & 11 & 100\end{array}$ $\begin{array}{llllll}67 & 86 & 62 & 67 & 100 & 100\end{array}$

60

33

40

75

100

33

100

25

20

$67 \quad 100$

100

60

33

17
17

100

33
33

33

22
56

$100 \quad 100 \quad 20$

67

17

67 
Taxon, family and name Number of quadrats

Sclerolaena bicornis

Sclerolaena brachyptera

Sclerolaena convexula

Sclerolaena decurrens

Sclerolaena diacantha

Sclerolaena divaricata

Sclerolaena intricata

Sclerolaena lanicuspis

Sclerolaena muricata

Sclerolaena obliquicuspis

Sclerolaena parallelicuspis

Sclerolaena patenticuspis

Sclerolaena spp.

Sclerolaena stelligera

Sclerolaena tricuspis

Convolvulaceae

Convolvulus clementii

Convolvulus remotus

Convolvulus spp.

Crassulaceae

Crassula colorato

Crassula spp.

Cucurbitaceae

* Cucumis myriocarpus

Euphorbiaceae

Chamaesyce drummondi

Euphorbia spp.

Sauropus trachyspermus

Fabaceae

Cullen cinereum

Glycine spp.

Lotus cruentus

* Medicago laciniata

* Medicago minima

* Medicago polymorpha

* Medicago spp.

Psoralea eriantha var. eriantha

Psoralea spp.

Swainsona greyana

Swainsona phacoides

\section{Gentianaceae}

* Centaurium spicatum

* Centaurium spp.

* Centaurium tenuiflorum

Geraniaceae

* Erodium cicutarium

Erodium crinitum

* Erodium malacoides

Goodeniaceae

Goodenia glauca

Goodenia gracilis

Goodenia pinnatifida

Goodenia spp.

Haloragaceae

Haloragis aspera

Haloragis spp.

Myriophyllum verrucosum

Lamiaceae

* Marrubium vulgare

Mentha australis

* Salvia verbenaca

Teucrium racemosum

Loranthaceae

Amyema lucasii

Amyema miraculosum subsp. boormanii

Amyema preissii

Amyema quandang var. quandang

\section{Vegetation communities}

$\begin{array}{cccccc}\mathbf{1} & \mathbf{2} & \mathbf{3} & \mathbf{4} & \mathbf{5} & \mathbf{6} \\ \mathbf{3} & \mathbf{3} & \mathbf{7} & \mathbf{2 1} & \mathbf{9} & \mathbf{1} \\ & & & & & \\ 33 & 33 & & 19 & & \\ & & & 14 & & \\ & & & & & \\ 33 & 33 & & & 11 \\ 33 & 33 & & & 56 \\ 33 & & 29 & 52 & 56 \\ & & 14 & 29 & 44 \\ & & 14 & 14 & 44 \\ & & & 5 & 11 \\ & & & 19 & \end{array}$

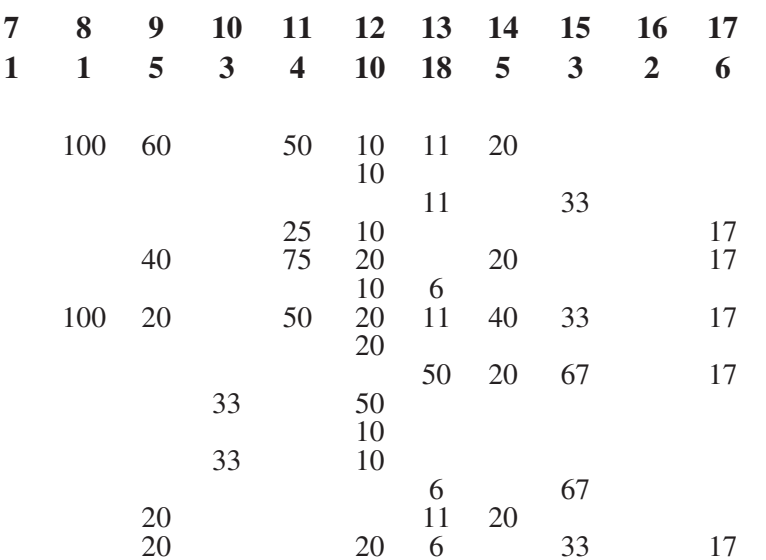

$\begin{array}{llllll}33 & 67 & 14 & 10 & 33 & 100\end{array}$

$\begin{array}{llllll}100 & 40 & 33 & 50 & 40 & 6\end{array}$

17

17
17

00

20

更

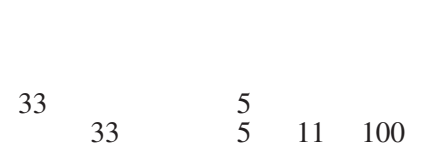

$\begin{array}{llll} & & & \\ & 20 & 33 & 25 \\ 100 & 40 & 33 & 25\end{array}$

6 
Taxon, family and name Number of quadrats

\author{
Abutilon fraseri \\ Abutilon leucopetalum \\ Abutilon otocarpum \\ Malva australiana \\ * Malva parviflora \\ Malvastrum americanum \\ Sida corrugata \\ Sida intricata \\ Sida spp.
}

Mimosaceae

Acacia aneura

Acacia ligulata

Acacia oswaldii

Acacia stenophylla

Acacia victoriae

\section{Myoporaceae}

Eremophila bignoniiflora

Eremophila duttonii

Eremophila spp.

Eremophila sturtii

Myoporum montanum

Myoporum platycarpum

\section{Myrtaceae}

Eucalyptus camaldulensis

Eucalyptus coolabah subsp. coolabah Eucalyptus largiflorens

\section{Oxalidaceae}

Oxalis corniculata

Plantaginaceae

Plantago cunninghamii

Plantago drummondii

Plantago turrifera

Polygonaceae

* Acetosa vesicaria

* Emex australis

Muehlenbeckia florulenta

Rumex brownii

* Rumex crispus

Rumex crystallinus

Rumex spp.

\section{Portulacaceae}

Calandrinia eremaea

Portulaca oleracea

\section{Proteaceae}

Hakea leucoptera

\section{Ranunculaceae}

Myosurus minimus var. australis

Ranunculus pumilio

\section{Rubiaceae}

Asperula gemella

Psydrax oleifolium

\section{Rutaceae}

Eriostemon linearis

Flindersia maculosa

\section{Sapindaceae}

Alectryon oleifolius subsp. canescens Atalaya hemiglauca

Dodonaea viscosa subsp. angustifolia

Dodonaea viscosa subsp. angustissima

\section{Scrophulariaceae}

Morgania floribunda

Stemodia florulenta

\section{Solanaceae}

Lycium australe

* Nicotiana glauca

Nicotiana spp.

\section{Vegetation communities}

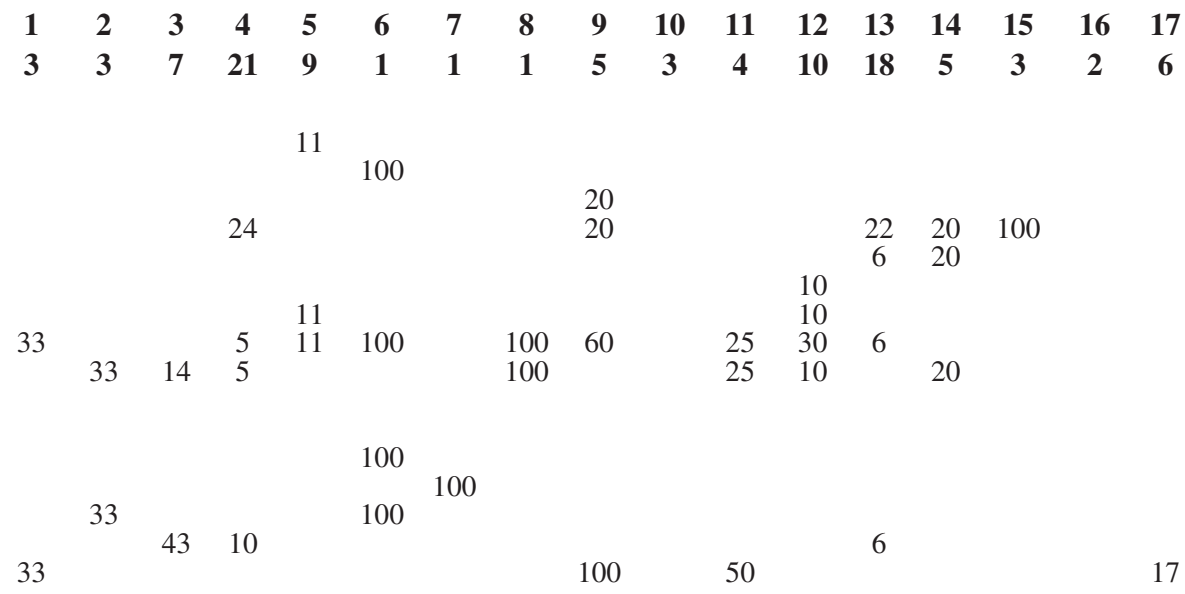

6

25

6 $\begin{array}{lll}33 & 5 & 100\end{array}$

$\begin{array}{ccccc}67 & 67 & 14 & 29 & \\ 67 & 33 & & 29 & 11\end{array}$

$86 \quad 57$

29

43

$$
100
$$$$
\begin{array}{lllll}
20 & 33 & & 10 & 17 \\
60 & & 75 & 30 & 28 \\
60 & 33 & 25 & 50 & 11
\end{array}
$$

$60 \quad 67$

50

100
14<smiles>[AlH]</smiles>

100
100

33
11

33

100
100 
Taxon, family and name Number of quadrats

Solanum esuriale

* Solanum nigrum

Solanum spp.

Thymelaeaceae

Pimelea trichostachya

Verbenaceae

* Verbena supina

\section{Zygophyllaceae}

Zygophyllum ammophilum

Zygophyllum apiculatum

Zygophyllum eremaeum

Zygophyllum spp.

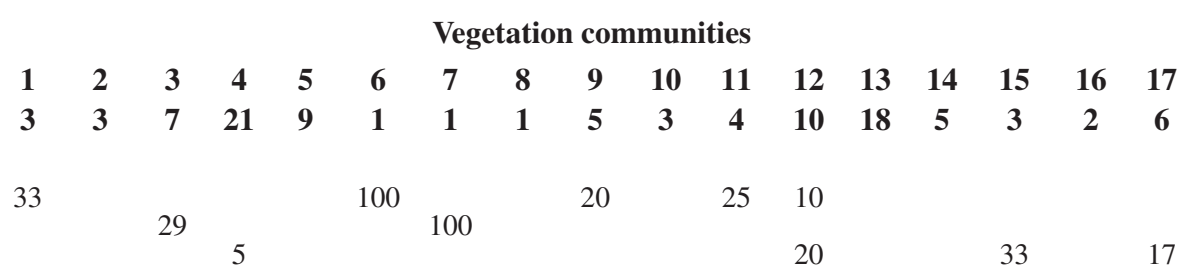

11

20

$25 \quad 40$

11

33 